\title{
DIREITO INTERNACIONAL NAS ARCADAS: A AULA INAUGURAL DE 16 DE FEVEREIRO DE 2009
}

INTERNATIONAL LAW AT THE ARCADES: AULA MAGNA OF 16TH FEBRUARY 2009

Paulo Borba Casella*

\begin{abstract}
Desculpai-me, senhores, por eu assim ocupar a vossa atenção. $\mathrm{O}$ estado próspero e animador em que se acha a nossa Faculdade, as suas tradições gloriosas, a sincera admiração que tributo à ilustração dos nossos mestres e colegas, prendem-me de tal modo, que não podia deixar de fazer estas considerações" - assim observava o lente substituto, Dr. Joaquim Augusto de Camargo, na Memória histórica acadêmica de $1877 .{ }^{1}$
\end{abstract}

As considerações que se seguem visam render homenagem à tradição da casa, de conferir a professor que recentemente acedeu à cátedra, a alegria e a responsabilidade de proferir a aula inaugural do ano letivo. Ao fazer esta, neste ano de 2009, cabe transcender o plano pessoal, para ver a interação deste, com algo mais amplo e mais duradouro - o plano institucional.

No plano pessoal reúnem-se dois dados vitais centrais: o Direito Internacional e a vida desta casa, que comecei a freqüentar ao ingressar na Faculdade de Direito do Largo de São Francisco, em 1978! Aqui me graduei, em 1982, aqui leciono Direito Internacional desde 1984. Aqui me doutorei em Direito Internacional, em 1986, aqui fiz a minha livre docência em Direito Internacional, em 1993. Aqui concorri duas vezes, e conquistei, em 2007, por quatro votos, em concurso, a cátedra de Direito Internacional Público, da qual tomei posse em 2008.

Trata-se, aqui, no tempo desta aula, de apresentar o conjunto da trajetória de mais de 180 anos de ensino ininterrupto de Direito Internacional nesta casa, sob a regência dos homens que conduziram tal cadeira, ao mesmo tempo em que se delineiam os grandes temas, nestes quase dois séculos: do Direito das Gentes, ao Direito Internacional clássico à percepção deste no contexto pós-moderno.

Cabe responder à comunidade - que nos financia, com parcela dos impostos do estado de São Paulo - cabe a advertência, quanto ao papel institucional, e a visão de como desempenhar esse esforço, e essa missão de ser professor de Direito do Largo

\footnotetext{
* Professor Titular de Direito Internacional Público e chefe do Departamento de Direito Internacional e Comparado.

1 FACULDADE DE DIREITO DE SÃO PAULO. Memória histórica acadêmica de 1877. São Paulo: s.n., 1878. (catálogo da Biblioteca central da Faculdade de Direito da U.S.P. 378.4:34(816.1)(091) RC F378.4 F128m e.7 S.E. tombo 09/87, cit. p. 2).
} 
de São Francisco, de levar adiante, e de manter a nossa tradição jurídica de excelência, especificamente no Direito Internacional. ${ }^{2}$

Proferir esta aula inaugural e justificar a escolha do tema: a presente lição sobre o 'Direito Internacional nas Arcadas' não se inscreve somente no sentido de reflexão sobre o papel do docente, mas, simultaneamente, sobre a importância do Direito Internacional no tempo presente - queiramos ou não, estamos insertos no contexto da pósmodernidade - e neste, ao lado da tradição, cabe perquirir o papel de cada um, no sentido de manter e desenvolver, em nossa escola, o estudo e o ensino do 'Direito das Gentes', como antes se chamava o Direito Internacional. É o papel, que me cabe desempenhar, na regência da prestigiosa cátedra de Direito Internacional Público, ao suceder aos mestres que, antes, a ocuparam, bem como, alternadamente, exercer a chefia do Departamento de Direito Internacional e Comparado. ${ }^{3}$

Mudanças recentes mostram a novidade e a especificidade do "estado da arte" no Direito Internacional, sob o impacto direto dos fatos, com ênfase em algumas características deste enquanto sistema institucional e normativo internacional - a internacionalidade como dado inerente e essencial do estudo e do ensino da disciplina: "não se pode fazer Direito Internacional no quintal de casa" dizia Irineu Strenger ${ }^{4}$ - não é possível deixar de olhar mais adiante do que cada um pode alcançar fazer; é preciso ser pensado e obrado como trabalho de equipe, entre os presentes, neste tempo e no encadeamento entre os tempos.

Depois destas considerações, será tratado o assunto, segundo perspectiva histórica, em três períodos, que permita ver grandes temas e momentos, olhar os homens e as obras, nos tópicos seguintes:

1. Da Independência à República

1.1.Grandes temas do Direito das Gentes

${ }_{2}$ Que outros venham relatar, como se se tratasse de grande descoberta, porquanto dizem os detratores ser o Direito Internacional a área jurídica que se divide em dois ramos: o Direito Internacional Privado, que não seria 'internacional', e o Direito Internacional Público, que não seria 'Direito' - com o que, de todo este, nada restaria, e daí se concluiria não existir Direito Internacional - a brincadeira seria cômica se não fosse trágica. Tal inanidade ainda encontra curso, de tempos em tempos. Mais vale seja este ataque apresentado, desde já e que falemos a respeito, para afastar o fantasma! Como tantas outras coisas na vida, mais vale enfrentar as dificuldades, que fugir delas, pois tudo o que não se resolve, de modo adequado, nos volta, e com força dobrada.

3 O que não é pouco. Deve ser, simultaneamente, motivo de alegria e conscientização da responsabilidade, que vai além do uso interno da casa. Reunir coisas de que gostamos é razão adicional para tentar ser objetivo a respeito, em relação ao que eu sinto e penso a respeito, para deixar entrever o mundo que se abre, a partir da entrada nesta casa, em relação ao Direito, como todo, e, especificamente, em relação ao Direito Internacional. Cabe transcender o plano pessoal, para ver a interação deste, com algo mais amplo e mais duradouro.

4 O professor Irineu Strenger costumava dizer que um professor de Direito Internacional não pode olhar somente para o quintal de casa! CASELLA, Paulo Borba. Direito internacional, vida e memória de Irineu Strenger (1923-2007). Revista de Arbitragem e Mediação, São Paulo, a. 4, n. 15, p. 11-18, out.-dez. 2007. 
Percebe-se a diversidade das situações históricas e das tendências da prática, marcada pela diversidade de soluções, mas estas não devem impedir a determinação de linhas gerais da evolução do Direito Internacional, o que se reflete na diversidade de tratamento da matéria, pela doutrina. A linha geral será no sentido de apontar as grandes linhas da condução do ensino do Direito Internacional, na tradição da nossa escola. Tratase de situar o Direito Internacional no conjunto da formação jurídica, onde se mostre a permanência de conceitos e dos princípios.

A história desta escola se imbrica, se mescla, se liga à história do país, e de modo assinalado, quantas das questões aqui suscitadas tiveram e tem impacto sobre o que em âmbito nacional se enfrentaria - já foi, muitas vezes, dito, e ouvir-se-á outras vezes - e isto se dá não somente no passado. ${ }^{5}$

Até hoje se discute e se questiona a questão da identidade nacional. E do papel de cada um dos elementos componentes desta, e dos elementos caracterizadores de uma cultura brasileira. ${ }^{6}$ Nesta casa não somente se estudam leis - porquanto estas mudam mas, se põem vertentes para o estudo e a compreensão do direito, e, mais adiante: a questão da inserção nacional, a formação de escola de Direito Internacional, característica deste país, porquanto esta não é somente escola de direito, mas também escola de governo.

\section{Da Independência à República}

A identidade nacional se fez concomitantemente ao funcionamento desta escola, à formação de sistema jurídico nacional, e de tradição, ao mesmo tempo, legal e humanista, desta escola, nesta escola, e, a partir dela, repercute para o estado, para o país, e forçosamente, também para o plano internacional E se transforma, se adapta e se renova. ${ }^{7}$

\footnotetext{
5 A criação de cursos superiores quando se instaura um país, como se deu no então recém-instaurado império brasileiro, não negligenciou o papel destes, para a formação não somente de quadros de gestão - como se desejava e se declara desde o início, e evitar que se mantivesse a subordinação intelectual - e mais do que isso, em relação à célula-mãe, a Faculdade de Direito de Coimbra. Também se exprime essa criação como dado de formação e de afirmação de identidade nacional, que então se esboçava.

6 AZEVEDO, Fernando de. A cultura brasileira: introdução ao estudo de cultura no Brasil. 4. ed. rev. e ampl. Brasília: Ed. UnB, 1963; SODRÉ, Nelson Werneck. Sintese de história da cultura brasileira. 9. ed. Rio de Janeiro: Civilização Brasileira, 1981; WEFFORT, Francisco; SOUZA, Márcio (Orgs.). Um olhar sobre a cultura brasileira. Prefácio de Fernando Henrique Cardoso. Rio de Janeiro: Associação dos Amigos da FUNARTE / Brasília: MinC, 1998.

7 CASELlA, Paulo Borba. Fundamentos do direito internacional pós-moderno. Prólogo de Hugo Caminos. São Paulo: Quartier Latin, 2008; esp. item XIII, 'boa tradição e a que se deve evitar'; CASELLA, Paulo Borba. abz: ensaios didáticos. São Paulo: Imprensa Oficial do Estado, 2008. cap. cit., p. 79: “A análise do legado da tradição serve para evidenciar valores e critérios de condução da prática estatal externa do Brasil independente : quando esta é boa, pode dar bons frutos ; quando não o for, ao menos poderá ser, no futuro, evitada, para que não se repitam os erros Desde cedo, no plano internacional, defende a igualdade jurídica dos estados e a solução pacífica de controvérsias. Poderiam estes ser dados relevantes, para a política externa e
} 
E continua a ser a referência, para o bem e para o mal, neste país, em matéria de ensino jurídico.

Para a formação do Brasil independente teve-se o cuidado de prover duas Academias de Direito, na qual pudesse formar-se a élite nacional - de modo a não mais ser inexorável deslocar-se para Coimbra ou alhures, para a formação profissional, como intelectual e de vida. Façam-se as críticas que se fizerem, dentre os elementos para tal formação, desde o início do funcionamento das duas academias (março de 1828 para a de São Paulo e maio do mesmo ano, para a de Olinda) determinou-se o ensino e o estudo do Direito das Gentes! Esse ensinamento nunca se interrompeu no Largo de São Francisco, ${ }^{8}$ diversamente do que ocorria, simultaneamente, em diversas universidades européias. ${ }^{9}$

Entre a pretensão da tabula rasa e a não menos enfadonha sucessão universal, a prática se alinha por via intermediária: a questão central sera a de determinar em que medida os estados se vinculam pelo legado institucional e normativo internacional, quer se trate de novos estados, como de outros já existentes - qual o papel da vontade dos sujeitos e qual a extensão da normatividade institucional, que transcenda as vontades de cada um dos componentes do sistema - e como se reflete isso na passagem entre os docentes que se sucedem na regência de uma cátedra, como a de Direito Internacional, em escola como a nossa.

Fica claramente indicada a tendência no sentido de mostrar-se diversidade na doutrina, mas, tratar-se-ia de dizer, ao contrário, a medida na qual pode ser assinalada certa tendência conceitualmente consistente e que evidencia a permanência dos temas, em suas grandes linhas, condicionados pelo tempo: cada geração traz a marca do seu momento histórico.

A partir de quando, como e por meio de quais elementos e de dados de funcionamento do sistema, se pode dizer que exista Direito Internacional? Como se forma tradição de estudo e de conhecimento de Direito Internacional, em um país, em uma universidade? O debate não é novo, é complexo, e fica para ser continuado.

Na realidade, a única questão, realmente significativa, será a de se determinar em qual medida terá lugar o reconhecimento da personalidade jurídica internacional porque suscita tanta controvérsia a aceitação crescente do ser humano como sujeito de Direito Internacional? como também a sucessão, entre gerações, na docência do Direito Internacional? como se faz? quando? sob quais meios e quais formas?

\footnotetext{
a atuação internacional do Brasil, perfeitamente consentâneos com o Direito Internacional pós-moderno e as exigências de inserção mundial em contexto cada vez mais competitivo".

8 Tanto mais surpreendente parecerá contrapor-se-lhe a supressão da obrigatoriedade deste, e a inserção do Direito Internacional público ou privado como uma dentre várias disciplinas optativas, no regime federal do currículo mínimo, para os cursos de Direito, tal como vigeu de 1972 até 1994!

9 Pouco vou falar hoje quer sobre a mãe coimbrã ou sobre a irmã pernambucana.
} 
Para Prosper Weil (1970) ${ }^{10}$ a aparição dos particulares no cenário do Direito Internacional constitui ilustração dos enriquecimentos que este pode deduzir:" "a mutação profunda pela qual passa, na hora atual, o Direito Internacional, tornando-se pouco a pouco - ao menos em algumas de suas partes - um direito da cooperação e um direito operacional", mediante o concurso e em favor dos particulares, ${ }^{12}$ que esses novos aspectos da vida internacional se desenvolvem. ${ }^{13}$

Permanece a questão central: pouco importa quais podem ser as situações de fato: a diversidade aparece a partir da multiplicidade de fatos, enquanto a unidade poderá aparecer sob a ótica do Direito Internacional enquanto conjunto, enquanto instrumental institucional e normativo, enquanto modo de ver o mundo.

As situações serão necessariamente diferentes, mas não será por isso que as normas terão de ser totalmente distintas, não será preciso reinventar a roda a cada geração, mas não se pode deixar de ver quando muda e quanto mudou o mundo nestas gerações, desde a instauração da veneranda cátedra de Direito Eclesiástico, diplomático e das gentes, tal como enceta o magistério Avelar Brotero, de 1828 até aposentar-se este em 1871, e desde então.

A matéria conta marco relevante: o ensino do Direito Internacional se põe desde o primeiro momento entre nós - é, ademais, a aula inaugural do curso da Faculdade de Direito de São Paulo, em março de 1828 - esse dado confere categoria histórica ao Direito Internacional nesta casa: justamente se mantém e se renova, ao longo das décadas, até o momento presente - muda e se renova o Direito Internacional, ao mesmo tempo em que se inscreve no conjunto do ensino jurídico, nesta casa e neste país.

\subsection{Grandes temas do Direito das Gentes}

Entre o fim do século XVIII e o início do XIX: a independência dos EUA e das antigas colônias da Espanha e de Portugal nas Américas trazem mutação estrutural do sistema internacional. Esse Direito Internacional emanado do Congresso de Viena, trazia, em seu bojo, a construção de jogo internacional entre velho e novo mundo: busca da

${ }^{10}$ WEIL, Prosper. Droit international public et droit administratif. In: Mélanges offerts à Mr. le Doyen Louis Trotabas. Paris: L.G.D.J., 1970. p. 511-528).

11 Id. Ibid., (art. cit., 1970, p. 526).

12 Id. Ibid., (art. cit., 1970, p. 527): «Le phénomène de la coopération active dépasse cependant à la fois celui de l'organisation et celui de la diversification des sujets de droit international, puisque cette coopération joue parfois sur le plan interétatique, sans qu'il y ait création d'une organisation internationale, et que dans certains cas le bénéficiaire en est un état et non un particulier».

13 Prosper Weil desenvolverá tais reflexões em seu curso geral, (WEIL, Prosper. Le droit international en quête de son identité. Recueil des Cours de l'Académie de Droit International, Haye, n. 237, p. 4-370, 1992. p. 9370). 
inserção dos novos estados - essa inserção de conjunto de novos estados traz renovação e ampliação do sistema: quanto ao número de participantes, quanto ao âmbito geográfico e quanto ao elenco temático - e a determinação da natureza da liberdade de navegação dos rios internacionais, do estatuto e categorias de representantes diplomáticos, dentre temas que prosseguirão até nossos dias entre número crescente de estados, com processos de negociação e de reconhecimento de tais mudanças, até a instauração de sistema institucional e normativo não mais somente europeu, mas europeu e interamericano (tratado de Lisboa, de 1825 - reconhecimento formal da independência do Brasil, e base para a inserção entre os pares do novo sujeito de Direito Internacional).

Antonio Pereira Pinto $(1864)^{14}$ já apontava a função precípua do Direito

Internacional, para regulamentar e solver conflitos entre estados de poderio marcadamente desigual:15 "a jurisprudência que se encaminha a estabelecer a confraternidade entre os povos do universo, ligando-os pelos nós do comércio, das indústrias e da propagação de todos os conhecimentos úteis, que tem por alvo realizar a solução das desavenças entre as nações pelos meios da discussão ilustrada e calma, é uma das mais belas conquistas da inteligência humana". ${ }^{16}$

${ }_{14}$ PINTO, Antonio Pereira. Apontamentos para o direito internacional. Brasília: Ministério da Justiça / UnB, 1980. v. i, 'aos leitores', p. 1-2) : “é lícito todavia ponderar que, achando-se esparsos os tratados que temos celebrado com diferentes potências estrangeiras e outros inéditos, a reunião deles em um só corpo, acompanhada de sucintas apreciações históricas, como o fizemos, da transcrição de documentos hoje raros, e da legislação peculiar às convenções mais importantes, deve, sem controvérsia, aproveitar àqueles que intentarem escrever o Direito Internacional brasileiro. E assaz compensados seremos dos labores desta tarefa, se para a edificação daquele grandioso edifício servir de pequeno seixo o nosso insignificante trabalho".

15 Id. Ibid., 'introdução' p. 3-4) : 'E, se infelizmente essa jurisprudência não tem atingido toda a perfeição de que é suscetível, se o orgulho das grandes potências impele-as ainda a lançar mão dos remédios violentos para extorquirem dos povos fracos concessões humilhantes e vantajosas somente à sua avidez, se contra nosso próprio país tem sido cometidas enormes vexações por um dos estados mais poderosos da Europa, apezar dos tratados, ou por causa dos tratados, se em geral o Império não tem auferido grandes lucros com a celebração dos contratos internacionais, tais fatos nem abalam a doutrina que deixamos expendida, nem por motivo deles devemos confiar menos em que uma reação se há de ir operando, entre as nações cultas, ou para referearem os ímpetos belicosos de seus governos, apontando-lhes a trilha da discussão diplomática como oportuno e exclusivo recurso, para terminar as dissidências que acaso apareçam com estranhos países, ou para aconselharlhes que nos tratados com os estados de ordem menos importante guardem sempre a devida reciprocidade, não lhes impondo pactos leoninos que trazem ordinariamente em si o gérmen de futuras contestações".

${ }^{16}$ Id. Ibid., 1864, loc. cit.: "Radicado, pois, esse pendor que se vai manifestando entre os países cultos para desenlaçarem pacificamente, pelos meios diplomáticos, e não pela espada do mais forte, as dissenções que surgem entre os povos e apertadas as suas relações de mútuo comércio e alianças pelo desenvolvimento do vapor e da eletricidade, não longínquos horizontes se devassam ao olho do observador perspicaz, nos quais se enxerga a lisonjeira época de uma tão perfeita e recíproca uniformidade de interesses internacionais, que não poderá ser violada, ainda pelos estados poderosos, sem total detrimento de sua prosperidade e grandeza. E, pois, a aproximação dessa lisonjeira situação deve ser fervorosamente almejada por todos os homens generosos, por todos os estadistas e filantropos". 


\subsection{Os pioneiros Avelar Brotero e Amaral Gurgel}

O Conselheiro Dr. José Maria de Avelar Brotero ${ }^{17}$ foi o primeiro professor de Direito do país, nomeado pelo Imperador Pedro I. Coube a Brotero proferir a lição inaugural desta Faculdade, em março de 1828. Regeu a nossa cadeira, alternando-a com o (também) Conselheiro Dr. Manoel Joaquim do Amaral Gurgel.

Teria sido a primeira obra de Direito Internacional, publicada no país, Questões sobre presas marítimas, de José Maria Avelar Brotero, editada em 1836, ${ }^{18} \mathrm{em}$ São Paulo. Em segunda edição, em 1863. ${ }^{19}$

Avelar Brotero, ao encetar o livro (1836), dirige-se "aos leitores", com a assertiva: "eu vou tratar de - Direito Positivo - e por isso o meu desejo e obrigação é mostrar-vos quais os tratados, manifestos e mais peças diplomáticas, que existem sobre o presente objeto; quais as leis, regulamentos e determinações das Nações sobre o seu direito - marítimo particular: quais as decisões dos tribunais das Nações influentes, e quais seus usos e costumes que formam o Direito das Gentes tácito ou voluntário. Eu procuro seguir o método ensinado por Klüber - dogmático-histórico - esclarecendo as matérias com fatos, com acontecimentos reais. Recorro ao Direito das Gentes absoluto, quando o caso é duvidoso, ou quando sobre ele não concordam as convenções e os usos. Desprezo as opiniões dos antigos escritores (aqueles que tive ao meu alcance), que só se fundam no Direito Romano ou seguem opiniões particulares, filhas ou da localidade, ou do partido". ${ }^{20}$

\footnotetext{
${ }^{17}$ Pensem na história da casa, na próxima vez em que passarem pela rua Conselheiro Brotero ou pelo Largo do Arouche ! Vivia o professor Brotero às turras com o primeiro diretor da casa, José Arouche de Toledo Rendon, que várias vezes escreve ao Imperador, pedindo que o remova do cargo, "antes que venha ter às vias de fato com este senhor" - Dom Pedro condecora o diretor, e este permanecerá no cargo, até 1833.

${ }^{18}$ BROTERO, José Maria de Avellar. Questões sobre presas marítimas. 2. ed. São Paulo: Typographia de Costa Silveira, 1836; "oferecidas ao cidadão Rafael Tobias de Aguiar, pelo autor J. M. A. Brotero" declara-se "atento venerador" de Tobias de Aguiar e faz-lhe dedicatória: "Com a proteção de V. Exa. me animo a fazer publicar uma pequena obra com o título - Questões sobre presas marítimas - fruto de algum trabalho, e que julgo servirá para dar algumas idéias àqueles que tem de julgar e defender objetos tão interessantes. A benevolência de V.E. relevará a falta de estilo, e os erros da doutrina; doutrina assaz espinhosa e bem pouco conhecida entre nós. Não tendo eu ao meu alcance senão os meus próprios livros, heide por força cair em omissões." (...) Exemplar da Biblioteca da FDUSP.

${ }^{19}$ Id. Ibid., registra no prólogo: "Conheço que este meu trabalho é imperfeito, e muito sinto que nesta segunda edição ficasse com tantos erros, resta-me a esperança que os homens competentes hão de ter indulgência com tais defeitos, e só censurar a doutrina e nesta parte peço-lhes severidade, pois pedir considerações seria ter em pouco a ciência e o meu dever. / Este livro não é uma obra de teorias ou doutrinas especulativas; é um compêndio de fatos e princípios do Direito Marítimo admitido pelas nações civilizadas. / Da primeira edição suprimi tudo quanto me pareceu fora da matéria, aumentei porém muita doutrina que faltava. / Cito os escritores, de que tenho notícia, que publicaram suas obras depois da minha primeira edição - 1836. / Nesta segunda edição procurei ser útil aos meus Escolares, no estudo do Direito das Gentes, e não olhei, nem me lembrei, que o meu trabalho pudesse ser estimado pela elegância e pureza de linguagem". Exemplar da Biblioteca da FDUSP.

${ }^{20}$ Id. Ibid., (1836, "aos leitores", sem número de página) : “Muitas vezes, na confusão dos pareceres dos JJ. entre si contraditórios eu me animo a dar a minha opinião. A legislação pátria é citada nos lugares competentes.
} 
Não parece ter mudado a realidade da política internacional, desde então: "As Nações reconhecem o odioso de tal procedimento, e sempre procuram defenderse com falsas razões, fazendo recair em seus adversários a causa das hostilidades". ${ }^{21} \mathrm{~A}$ mesma reflexão pode ser suscitada a respeito dos bombardeios entre Israel e Hamas, em janeiro de 2009!

Ao considerar "que direito a Nação adquire por meio da guerra" (par. XXIII) $)^{22}$ passa Brotero: "Verdadeiramente a guerra não tem outro fim senão - paralisar as forças do inimigo obrigando-o desta maneira a reconhecer os princípios de eqüidade, $\mathrm{e}$ prestar-nos a justa satisfação".

Os limites ao uso da força constituem, ainda, lição crucial para todo o conjunto do Direito das Gentes. E a determinação de tais limites continua a ser objeto de controvérsias. $^{23}$

Caberia referir, ainda, outra obra, Princípios de Direito Natural "compilados por José Maria Avellar Brotero, lente do primeiro anno do curso jurídico de São Paulo", publicado no Rio de Janeiro, na "Typographia Imperial Nacional", em 1829. Obra sobremodo curiosa, e que mereceria ser resgatada.

Muito desejava alegar os julgamentos dos nossos tribunais, mas não estava ao meu alcance poder satisfazer o meu desejo. / Eu conheço que o meu trabalho está bem longe da perfeição e conheço que ele está muito longe de poder conseguir o seu fim : conheço e confesso que não tive à mão nem a legislação das Nações do norte da Europa, nem muitos bons autores que tem tratado desta matéria, e que eu devia consultar; mas minha consciência está convencida de que esta minha pequena obra sempre há de prestar alguma utilidade aos meus escolares, e ao público. Julgo que a matéria é muito interessante, e que por esta razão o governo, e os sábios, não me deixarão continuar a transmitir na aula minhas opiniões à mocidade, uma vez que elas sejam falsas. O governo me advertirá e os sábios me esclarecerão, com suas luzes, por meio da imprensa”. Como se vê, adotava redação diversa da que figura na segunda edição (1863).

${ }^{21}$ BROTERO, José Maria de Avellar. Questões sobre presas maritimas. 2. ed. São Paulo: Typographia de Costa Silveira, 1836. p. 9; redação diversa na edição de 1836, p. 5-6: "mas em regra de direito, abusos não formam lei, e tais exemplos das Nações também não a podem formar, visto que elas mesmas reconhecem o odioso e ilegal de tal procedimento, defendendo-se com pretextos de uma falsa necessidade, ou procurando provar que sua adversária já tinha iniciado as hostilidades, e que portanto não era necessária a declaração; asserção reconhecida entre todas as Nações, princípio este verdadeiro e que nós confessamos : mas na história só o achamos aplicado a pretextos, que servem para escurecer a verdade, e muitas vezes sem o menor fundamento." (...) "Contudo, a mesma Inglaterra não se atreve a negar o princípio da necessidade da declaração de guerra, para a legalidade da presa, e só sim estabelece como princípio seu - o direito de reciprocidade".

22 Id. Ibid., (1836, p. 105-110; 1863, p. 88-90).

${ }^{23}$ CASELLA, Paulo Borba. ONU pós-KELSEN. In: MERCADANTE, Araminta de Azevedo; MAGALHÃES, José Carlos de. (Orgs.). Reflexões sobre os 60 anos da ONU. Ijuí: Ed. Unijuí, 2005. p. 13-64. 
Estes Princípios (1829) ${ }^{24}$ somente incidentalmente tratam de questões do que se poderia denominar Direito Internacional. Mas, em razão da controvérsia, que à época suscitaram, merecem menção específica. ${ }^{25}$

Nos Princípios de Direito Natural (1829), adverte Brotero “Aos Leitores": "Se a vossa censura é filha da maledicencia e capricho, sois uns entes nullos no Universo; se ella porém é filha do amor da verdade, então sois homens bem fazejos, e imitaes ao Creador. / São Paulo, 21 de dezembro de 1828 / J. M. A. B.”.

Avelar Brotero considera o "estado de necessidade" (par. 23, p. 40-42): “A faculdade moral de desprezar a lei mais fraca, para que se obedeça, por causa do conflito, à lei mais forte, se chama direito de necessidade". Detalha três hipóteses deste: " 1 '. Direito de necessidade absoluta e hipotética extrema. $2^{\circ}$. hipotética não extrema. $3^{\circ}$. Necessidade simples, isto é, sem complicação de perfeições".

Para dar indício de quanto permanece atual o tema do estado de necessidade em Direito Internacional foi objeto do inteiro colóquio de Grenoble, da Sociedade francesa para o Direito Internacional (realizado de 8 a 11 de junho de 2006). ${ }^{26}$

Observava Waldemar Ferreira (1928) ${ }^{27}$ ter José Maria Avellar Brotero (17981878) lecionado na Faculdade durante quarenta e quatro anos, "pois que se jubilou em 22 de novembro de 1871, de modo que quase durante meio século, a sua vida se entremeou com a da Faculdade de Direito, à qual prestou serviços assinalados, que não podem ser deslembrados, sem embargo de ter o seu compêndio, elaborado para os estudantes, Princípios de Direito Natural, provocado a crítica mais acerba, a ponto da Comissão de Instrução Pública da Câmara dos Deputados, em 1830, ter apresentado parecer, que foi aprovado, concluindo que não fosse este admitido no curso jurídico, 'devendo-se ensinar o Direito Natural por outro compêndio, que melhor desempenhe a matéria'. ${ }^{28}$

Além dos Princípios de Direito Natural (1829) e das Questões sobre as presas marítimas (1836 e 1863), Brotero publicou Princípios de Direito Público universal: analyse de

\footnotetext{
${ }^{24}$ BROTERO, José Maria Avellar. Principios de direito natural. Rio de Janeiro: Typographia Imperial Nacional, 1829; "compilados por, lente do primeiro anno do curso jurídico de São Paulo". Exemplar da Biblioteca da FDUSP.

${ }^{25}$ A Avellar Brotero teria cabido não somente escrever a primeira obra de Direito Internacional Público do Brasil, mas, se considerarmos os Princípios de direito natural (1829), teria esta sido objeto de escândalo e de controvérsia, um ano depois de publicada. Como adiante se examina.

${ }^{26}$ Société française pour le droit international, la necessité en droit international (colloque de Grenoble, Paris: Pedone, 2007) onde o eixo das discussões se põe entre «nécessité fait loi» e «nécessité n’a point de loi», ou seja, a necessidade faz a lei, ou a necessidade não tem lei?

${ }^{27}$ FERREIRA, Waldemar. A Congregação da Faculdade de Direito de São Paulo na centúria de 1827 a 1927 (separata da Revista da Faculdade de Direito de São Paulo, São Paulo : Typographia Siqueira, 1928).

${ }^{28}$ FERREIRA, Waldemar. op. cit., p. 33-34).
} 
alguns paragraphos de Wattel (São Paulo, 1837, 80 p.) $)^{29}$ e Philosophia do direito constitucional (São Paulo, 1868, 166 p.). ${ }^{30}$

Miguel Reale (1955, 1956, 1962 e 1976) $)^{31}$ reporta a respeito: "primeiro lente da Faculdade de Direito de São Paulo, acumulando as funções de secretário com proverbial exação, durante quarenta e três anos" (...) "timbrou em ser o mais rigoroso cumpridor dos deveres do magistério, até jubilar-se aos 22 de novembro de 1871, tendo adquirido a cidadania brasileira um lustro após a sua fixação em São Paulo, em junho de 1833". ${ }^{32}$ Relata Reale extensamente a controvérsia em torno do compêndio, Princípios do direito natural (1829). ${ }^{33}$

Cabe construir a sucessão dos docentes (ordinários, catedráticos e titulares da cadeira de Direito Internacional), a partir deste seu primeiro ilustre regente. Conforme registra a Memória histórica acadêmica de 1877, da Faculdade de Direito de São Paulo, “a

29 Miguel Reale (1955, editado 1956, 1962 e 1976, cit., nota 17) : “Cs. Avelar Brotero - Questões sobre presas marítimas, da qual se tiraram duas edições, uma em 1836 e a outra em 1863, esta com acréscimos. Além deste livro e dos Princípios, mais dois foram, com segurança, por ele publicados: Princípios de direito universal, folheto de 80 páginas, aparecido anônimo em 1837, conforme declaração do autor em seu "livro-mestre" (Cs. Traços Biográficos, cit., p. 75) e mais um drama político intitulado Tumulto do povo em Évora, de 102 p., publicado também em São Paulo. Por outro lado, Brotero não chegou a publicar os anunciados Princípios históricos compilados para servir de preliminares ao Compendio de Direito Natural e Direito Público. É possível que só haja existido apostilas. Sacramento Blake em seu Dicionário Bibliográfico Brasileiro, alude a mais dois trabalhos: Filosofia do direito constitucional (São Paulo, 1868, 166 p.) e Os três primeiros parágrafos de Vattel - Direito das Gentes, liv. I, cap. 1. Princípios de direito público universal ou filosofia do direito constitucional, dividido em 20 lições. Creio que esta obra não seja senão o folheto de 80 páginas, acima referido, que também é anônimo, abrangendo número idêntico de páginas e de lições. Há na Biblioteca da Faculdade um exemplar com a dedicatória de Avelar Brotero de próprio punho, com estes dizeres: 'Oferecido à Biblioteca pelo A.' O título dessa edição de 1842 já é diverso, Filosofia do direito constitucional, embora no subtítulo se encontrem as referências a Vattel. Terá havido nova edição dessa obra, ampliada para 116 p., em 1868, como afirma Sacramento Blake? É o que não pude averiguar".

${ }^{30}$ BROTERO, José Maria de Avellar. A filosofia do direito constitucional. Introdução de José Afonso da Silva. São Paulo: Malheiros, 2007. p. 18-19: "Merece especial destaque este volume, que temos em mãos, A filosofia do direito constitucional (São Paulo, 1842). Miguel Reale acredita que seja este a reprodução daquele folheto de 80 p. publicado em 1837. Pode ser, mas talvez reformulado e ampliado. Vale a pena ler e examinar este texto sobre a filosofia do direito constitucional, que apresenta surpresa agradável para o constitucionalismo brasileiro, ainda que ele não seja sobre direito constitucional positivo, pois não se refere à Constituição do Império".

31 REALE, Miguel. Avellar Brotero, ou a ideologia sob as Arcadas. In: Horizontes do direito e da história: estudos de filosofia do direito e da cultura. São Paulo: Saraiva, 1956. p. 195-224, (1955, publicado originalmente neste volume )depois publicado em São Paulo: Grijalbo / EDUSP, 1976, p. 63-91. (1. ed. 1962).

32 REALE, Miguel. Filosofia em São Paulo. 2. ed. rev. e reestruturada. São Paulo: Grijalbo / EDUSP, 1962 (ed. 1976, p. 64, nota 1, cita): "Notas” autobiográficas, coligidas por seu neto em BROTERO, Frederico de Barros. Traços biográficos do Conselheiro José Maria Avellar Brotero. São Paulo, 1933. p. 71 ss.

${ }^{33}$ REALE, Miguel. op. cit., p. 74: "O que nos atrai, todavia, na personalidade de Brotero, não são as atitudes do ranzinza impenitente ou do orador que baralhava sílabas e frases, mas sim a significação histórica, mais do que o valor intrínseco de sua obra filosófica-jurídica, inclusive para compreender-se melhor a sua presença na cátedra de Direito Natural durante quase meio século". 
Faculdade tem tido, desde o dia de sua inauguração os quarenta lentes seguintes, dos quais 12 jubilaram-se, 6 faleceram no exercício do cargo, e 6 demitiram-se deste". ${ }^{34}$ Jubilaram-se:

$1^{\circ}$. Dr. J. M. de Avellar Brotero, que foi nomeado por Decreto de 12 de outubro de 1827, e jubilou-se em 1871(...)

"6 ${ }^{\text {. }}$ Conselheiro Dr. Manuel Joaquim do Amaral Gurgel, que, nomeado a 20 de fevereiro de 1834, jubilou-se em 1859". Amaral Gurgel foi também diretor da Faculdade, nomeado por Decreto de $1^{\circ}$. de dezembro de 1837 , tomou posse a 23 de fevereiro de 1838".

Avelar Brotero ${ }^{35}$ e Amaral Gurgel teriam, assim, regido, alternadamente a cadeira de Direito das Gentes. De 1827 a 1871, no caso do primeiro, e de 1834 até 1859 , no caso do segundo.

Manoel Joaquim do Amaral Gurgel nasceu em São Paulo, a 8 de setembro de 1797, onde faleceu a 15 de dezembro de $1864 .{ }^{36}$ Participou do movimento da independência, tendo sido, por isso, deportado. Formou-se, em 1832, pela Faculdade de Direito de São Paulo, onde se doutorou, em 1834. Ocupou a cátedra de filosofia no curso anexo (1829), lente substituto da Faculdade de Direito (1833), deputado provincial (1834, 1842, 1847 , 1848), diretor interino (1837) e diretor efetivo da Faculdade de Direito, vice-presidente da província (1859-1864).

Amaral Gurgel foi poeta, tradutor do Catecismo de Bossuet, também historiador e biógrafo: a ele devemos a Notícia biográfica do general José Arouche de Toledo Rendon (São Paulo, 1843) - o primeiro diretor da Faculdade; bem como, no mesmo ano, a Oração fúnebre por ocasião das exéquias feitas ao revdmo. sr. padre Diogo Antonio

${ }^{34}$ FACUldADE DE DIREITO DE SÃO PAULO. Memória histórica acadêmica de 1877. Redigido por Joaquim Augusto de Camargo. São Paulo: s.n., 1878. (catálogo da Biblioteca Central da Faculdade de Direito da Universidade de São Paulo, 378.4:34(816.1) (091) RC F378.4 F128m e.7 S.E. tombo 09/87, cit. p. 2) com as observações já referidas do "lente substituto", Dr. Joaquim Augusto de Camargo.

${ }^{35}$ CENTRO DE DOCUMENTAÇÃO DO PENSAMENTO BRASILEIRO (Org.). Dicionário bio-bibliográfico de autores brasileiros. Salvador: CDPB / Brasília: Senado Federal, 1999. p. 119-120: "Coube-lhe a missão de implantar o curso jurídico em São Paulo, sendo o seu primeiro lente e acumulando as funções de secretário (cargo que exerceu por mais de quarenta anos)".

${ }^{36}$ MELO, Luís Correia de. Dicionário de autores paulistas. São Paulo: Comissão do IV Centenário da cidade de São Paulo / Serviço de Comemorações Culturais, 1954. p. 273: "Aprendeu as primeiras letras com a sua madrinha e parenta, Maria Policena do Amaral Gurgel, que se encarregou dos cuidados de criá-lo e educá-lo. Depois do estudo do latim com o professor André da Silva Gomes, matriculou-se no curso de teologia, que acabava de instalar-se no convento do Carmo, sob a direção de Frei Antonio do Bom Sucesso Mamede. Mais tarde, inaugurada no convento de São Francisco, a aula de filosofia de Mont'Alverne, inscreveu-se entre os seus discípulos. Pouco depois (1820), tendo-se instruído em outras disciplinas, foi nomeado pelo bispo D. Mateus, para reger a cadeira de história eclesiástica, recém-criada no seminário de São Paulo, substituindo ao mesmo tempo, o professor de exegética. Em 1816 recebeu ordem de presbítero, com dispensa da autoridade eclesiástica, por não ter idade legal. Foi, em 1821, nomeado examinador sinodal do bispado". 
Feijó, na igreja do convento do Carmo de São Paulo, em 1843 (São Paulo, 1843, 12 p., in $8^{\circ}$.).

Para J. R. de Lima Lopes, ${ }^{37}$ "até 1870, aproximadamente, as Faculdades de Direito não foram centros de debates. A vida cultural jurídica dava-se no foro ou na Corte. Quando o debate se acende, trata-se já de uma geração que virá, finalmente fazer a República". ${ }^{38}$ Curiosa a atitude de muitos intelectuais brasileiros: ao apontarem o florescimento das idéias na 'república' esquecem-se do tempo de maturação necessário, realizado durante o 'império'. Querem ver somente parte do quadro, a que mais lhes convenha?

2. de 1891 a 1966

Nessa altura o Brasil há pouco passara pela mudança de regime político - do império para a república - que ensejou nova negociação internacional, consideravelmente mais fácil, desta vez, visando ao reconhecimento do novo governo - a Rússia foi um dos últimos estados a reconhecer a República dos estados unidos do Brasil: somente o fez depois que o Imperador Pedro II, exilado, falecera em Paris.

O Direito Internacional vigente nesse tempo acolhia e regulava a ocupação colonial - as áreas de interesse e as zonas de influência na África e na Ásia foram reguladas pelo Congresso de Berlim e mesmo o IDI faz Resolução sobre a conquista colonial. Discursos como o da 'missão civilizadora do homem branco' passavam incólumes - faziam parte do espírito do tempo.

Martti Koskenniemi, em seu livro The gentle civilizer of nations: the rise and fall of international law 1870-1960 aponta o estado de desenvolvimento e as características principais do que foi o Direito Internacional, à época estudada, e compara a situação respectiva deste, entre a Alemanha, a França, a Inglaterra e a projeção para fora da Europa, através de Carl Schmitt, Hans Morgenthau e o significado da mudança de enfoque de Direito Internacional para relações internacionais, nos Estados Unidos. ${ }^{40}$

${ }^{37}$ LOPES, José Reinaldo de Lima. O direito na história: lições introdutórias. 2. ed. São Paulo: Max Limonad, 2002. p. 343.

${ }^{38}$ Id. Ibid.: "As queixas contra os cursos foram muitas, como a falta de freqüência dos professores, as fraudes nas listas de presença dos alunos, o dogmatismo e o tradicionalismo nas disciplinas. Os juristas desenvolvem, quando querem, uma espécie de autodidatismo, formam suas próprias bibliotecas. (...) O resultado é a tendência continuada de certas teses e tendências tradicionalistas : como por exemplo a aceitação não questionada do Direito Natural domesticado do século XIX, capaz de fazer conviver a Constituição com o escravismo e com uma religião de estado, transportando para o direito tabus cujo desrespeito leva à reprovação".

${ }^{39}$ KOSKENNIEMI, Martti. The gentle civilizer of Nations: the rise and fall of international law 1870-1960. Cambridge: University Press, 2001.(paperback ed., 2005).

${ }^{40}$ Isso é relevante e merece ser situado, pois ao menos se saberá do que se trata : você pode levar para casa e acreditar no que quiser - em quase tudo - mas, pelo menos saiba o que está comprando e o que vale o produto. 
Nessa mesma época, contudo, desenvolvimentos consideráveis começam a se esboçar, com as conferências de paz da Haia, de 1899 e 1907 e as convenções daí resultantes.

Até 1907, quando se reuniu, na Haia, o concílio dos povos cultos, apenas foi possível tentar a regulamentação da guerra, para que fosse menos cruel, e menos destruidora das creações materiais e morais, a quue a humanidade mais fortemente se afeiçôa, comentava Clóvis Bevilaqua $(1920)^{41}$ : “em 1919, realisou-se um grande progresso ethico-jurídico. A codificação levada a effeito não mais teve por objecto as leis da guerra, porém os princípios tendentes a comatel-a e reduzil-a. Agora, sim começaram os homens a legislar sobre a paz, a preparar as condições sociaes e jurídicas da paz. Antes não puderam senão legislar sobre a guerra". ${ }^{42}$

Grupos de eventos, ao longo do século XX: nova mutação estrutural do sistema internacional, após a primeira guerra mundial, com o fim dos impérios multinacionais (russo, otomano, austro-húngaro) e tentativa de se construir nova ordenação do sistema institucional e normativo - a Sociedade das Nações, a Corte permanente de justiça internacional, o Pacto de Paris, de proscrição da guerra, de 1928, sistema internacional de proteção das minorias étnicas. $\mathrm{O}$ sistema interamericano surge e se consolida nessas décadas.

Após a Segunda Guerra Mundial, advento do sistema da família da ONU e, em conseqüência da descolonização se estabelece cerca de centena de novos estados autodeterminação dos povos e proteção internacional dos direitos fundamentais. Ao cabo deste período a descolonização marca o advento de nova era para o Direito e as relações internacionais.

Desde $1945,{ }^{43}$ o Direito Internacional, acompanhou todas as transformações do contexto: da multiplicação dos sujeitos tradicionais de Direito Internacional, os estados,

Muita gente confunde 'Direito Internacional' e 'relações internacionais' sem saber do que se trata. Procurei situar diferenças conceituais entre Direito e relações internacionais: CASELLA, Paulo Borba. Fundamentos do direito internacional pós-moderno. cit. (2008, esp. item xii, 'direito e relações internacionais : coexistência pacífica?', p. 889-972).

41 BEVILAQUA, Clóvis. Prólogo. In: PEREIRA, M. F. Pinto. Soberania das nações. São Paulo: C. Teixeira \& Cia., 1920. p. ix-xii).

42 Id. Ibid.,: "Essa lição do conflito mundial, que o jovem internacionalista assignala, da solidariedade, que as nações alliadas mutuaram, durante a lucta, e que se continuará na paz, sem prejuízo das soberanias nacionaes, produziu um fructo de conseqüências inestimáveis, a constituição da Sociedade das Nações, que, com o fluir dos tempos, merecerá melhor essa denominação, quando a reorganisação de modo a ser uma cooperação perfeita de esforços, tendo por alvo o bem da humanidade, por base os direitos dos estados, a soberania, a egualdade, a jurisdição sobre o respectivo território, e por elemento plástico os princípios jurídicos, em sua mais pura idealização".

${ }^{43}$ RANGEL, Vicente Marotta. op. cit., p. vi: "sofreu o impacto perturbador dos fatores econômicos, sociais, políticos e tecnoloógicos ; acolheu novos sujeitos específicos, desde o ser humano, reidentificado à luz do Direito Positivo como pólo de irradiação e alvo de destino de todo ordenamento jurídico, até as organizações 
ao lado das organizações internacionais, bem como a emergência e a consolidação do ser humano como sujeito de direitos e de obrigações no plano internacional, como exprimem as garantias fundamentais (Declaração Universal de 1948 e os Pactos internacionais de direitos, de 1966) até o surgimento e o desenvolvimento do Direito Internacional Penal, com destaque para o Estatuto de Roma e a criação do Tribunal Penal Internacional.

1966 é o ano dos Pactos internacionais da ONU: direitos civis e políticos, direitos sociais, econômicos e culturais - a juridicização da proteção internacional dos direitos fundamentais, que começara com a Declaração universal de 1948 passa a ter novos marcos regulatórios com os dois Pactos de 1966.

\subsection{Percepção e tratamento dos temas}

As situações que se produziram em cada uma dessas fases deixam traços marcantes: e acarretam distinta orientação e tratamento diverso, na jurisprudência, na prática dos estados como na doutrina. Por quê a perspectiva histórica?

Em qualquer ramo do conhecimento, mas sobretudo no Direito Internacional (quer em relação a tratados, como também outras matérias, além destes) a clara importância do fator temporal e impacto dos modelos: "o direito, em todos os seus ramos, não opera no vazio" G. E. do Nascimento e Silva considerava na Haia (1977) ${ }^{44}$ o fator tempo e os tratados.

$\mathrm{Na}$ sucessão docente ocorre a dificuldade de definição de rumos e das grandes linhas, mas o conceito de base: entre estados, como entre gerações docentes - a transferência de conjunto de competências, sobre extensão territorial e temporal determinada.

Tratar-se-ia de conceber as competências dentro da soberania, enquanto conceito clássico do Direito Internacional: o grande problema é a definição, como se mostra também em relação aos grandes temas da matéria, como paradigmaticamente ilustra a responsabilidade internacional dos estados - a complexidade e os desdobramentos políticos tornam delicada a construção de normas puramente 'técnicas'.

Campos nos quais os dados jurídicos se alinham e se mesclam aos dados políticos - uns e outros, inexoravelmente ligados. Os dados jurídicos, enquanto

\footnotetext{
internacionais que, por seu turno, crescem, se diversificam e se reproduzem por si próprias; reavaliou as funções do estado, no contexto da sociedade global, embora sem desconhecer-lhe a presença e o prestígio de ator principal e indeclinável; acompanhou o relacionamento dos homens, em escala planetária e indagou, subseqüentemente, das condições dos cosmonautas e do regime jurídico dos corpos celestiais contactados ; e voltou a perquirir dos valores fundamentais de convivência humana e de ordem jurídica respectiva".

${ }^{44}$ SILVA, Geraldo Eulálio do Nascimento e. Le facteur temps et les traités. Recueil des Cours de l'Académie de Droit International, n. 154, p. 215-297, 1977.
} 
dados técnicos, permitem a construção de discurso lógico, sobre o qual a regulação pode ser estipulada. O 'erro' dos modelos convencionais teria sido, talvez, de colher indiscriminadamente as dimensões políticas, e deixar-se nortear por tais escolhas, no tratamento do assunto - que teriam enfraquecido a qualidade e a possibilidade de aceitação do Direito Internacional, enquanto expressão normativa.

A carreira professoral não é daquelas que nos conferem perfeita serenidade, advertia G. Burdeau (1970). ${ }^{45}$ Ainda caberá suprir a lacuna que nos resta, quanto às datas exatas do exercício da titularidade da cadeira de Direito das Gentes na Faculdade de Direito de São Paulo, ${ }^{46}$ nos vinte anos, entre a jubilação de seu primeiro regente, J. M. de Avellar Brotero, em 1871, até que se aponte o programa de ensino, apresentado em 1891, pelo catedrático Jesuíno Ubaldo Cardoso de Mello. Alguns nomes apontam, mas o exato encadeamento de tal sucessão faz falta.

Da pesquisa nos anuários da Faculdade de Direito, de 1891 até 196977, extrai-se a seguinte evolução do ensinamento do Direito Internacional na nossa casa : Jesuíno Ubaldo Cardoso de Mello, em 1891 e 1892, rege a primeira cadeira da segunda série do curso de ciências sociais, "Direito das Gentes, diplomacia e história dos tratados". Não há registro para 1893.

Em 1894 o programa de ensino de "Direito das Gentes, diplomacia e história dos tratados" foi apresentado pelo "lente cathedratico", Dr. Américo Brasiliense de Almeida Mello. Mais um lente catedrático de Direito das Gentes da casa que se tornará nome de rua desta cidade!

Em 1895, 1896 e 1898, o programa de ensino de "Direito Internacional Público e diplomacia" foi apresentado pelo "lente cathedratico", Dr. Alfredo Lima. Não há registro para o ano de 1897.

Nos anos de 1899 e 1900, o programa de "Direito Internacional Público e diplomacia” foi apresentado pelo "lente substituto", Dr. José Mariano Corrêa de Camargo

\footnotetext{
${ }^{45}$ BURDEAU, Georges. Sur un enseignement impossible. In: Mélanges offerts à Mr. le Doyen Trotabas. Paris: L.G.D.J., 1970. p. 41-50, cit. p. 41) «Quoique l'on en pense la carrière professorale n'est pas de celles qui assurent une parfaite sérénité d'âme. Parce que le cadre dans lequel elle se déroule demeure inchangé, parce que les programmes varient peu, parce que le cours magistral s'insère dans une immuable cérémonie, on croit que cet appareil des rites et des traditions constitue une carapace qui rend le professeur impérmeable aux curiosités et aux inquiétudes de son temps».

${ }^{46}$ SOARES, Guido Fernando Silva. Curso de direito internacional público. (op. cit., 2002, pp. 15-16) aponta, após o seu primeiro catedrático, o Conselheiro Avelar Brotero, ao qual (sic) "se seguiram os mestres Amaral Gurgel" (porquanto este a regeu alternadamente com o primeiro, de 1834 até 1859). A seguir menciona Ferreira França, sem dar deste as datas, seguido de Oliveira Coutinho, João (sic, José) Mendes, Brás Arruda e Vicente Marotta Rangel.

${ }^{47}$ Proficiente e cuidadoso levantamento Pesquisa nos Anuários da Faculdade de Direito (1891 a 1969), desenvolvido pela equipe da Biblioteca da Faculdade de Direito da Universidade de São Paulo, sob a direção da Dra. Maria Lúcia BEFFA. A toda a equipe ficam, aqui, mais uma vez, consignados, os meus efusivos agradecimentos.
} 
Aranha. Este docente, em 1901, passa a ser "lente cathedratico" e o programa, por vez primeira, menciona "Direito Internacional Público e privado e diplomacia".

De 1902 até 1911, o programa, com a mesma denominação "Direito Internacional Público e Privado e diplomacia", é apresentado pelo "lente substituto", Dr. José Bonifácio de Oliveira Coutinho.

Outro professor de Direito Internacional da nossa casa foi José Mendes (1861-1918). ${ }^{48}$ Por decreto de 3 de novembro de 1911 foi nomeado professor ordinário da cadeira de Direito Internacional Público e privado, da qual tomou posse em 11 do mesmo mês. ${ }^{49}$ Exerce a titularidade da cátedra, até ser assassinado em Mococa, no interior de São Paulo, em 1918.

De José Mendes foram publicadas as obras: Ensaios de philosophia do direito (São Paulo, 1905, 2 v.), Das servidões de caminho (Direito romano e pátrio) (São Paulo: Duprat \& Cia., 1906), Direito internacional Público (São Paulo: Duprat \& Cia., 1913)..$^{50}$

"Da interpenetração orgânica desses períodos e de sua ressonância no Direito das Gentes se dava conta há mais de seis décadas, no decorrer da primeira guerra mundial, em página ainda repassada de atualidade, José Mendes, que o prelecionava na Faculdade de São Paulo". ${ }^{51}$ Aqui há dado que merece ser destacado.

Oportuna a percepção da evolução histórica do Direito, conforme pondera V. Marotta Rangel: "Teria a análise do Direito das Gentes contemporâneo o efeito de prescindir da busca desse direito em tempos menos recentes? A leitura dos ensaios componentes da obra autorizará a resposta negativa e nos faz reconhecer neles a presença dos ensinamentos de José Mendes. O contemporâneo surge aí como resumo e complemento das fases anteriores, a que os ensaios recorrem toda vez que se faça necessário compreender e vistoriar os quadrantes e o cerne do direito perquirido". ${ }^{52}$

Para compreender o contemporâneo é preciso entender o que veio antes e poder conferir coerência ao conjunto, mediante a compreensão do que precede, para se chegar ao ora existente e daí para o que poderá vir a seguir. Destacar um momento fará perder a compreensão do todo.

\footnotetext{
${ }^{48}$ CENTRO DE DOCUMENTAÇÃO DO PENSAMENTO BRASILEIRO (Org.). Dicionário bio-bibliográfico de autores brasileiros. Salvador: CDPB / Brasília: Senado Federal, 1999. p. 317-318.

49 FERREIRA, Waldemar. op. cit., p. 109-110.

${ }^{50}$ Id. Ibid.; menciona, inadvertidamente, 1915 como data da publicação do Direito internacional público: preleções do Dr. José Mendes "Professor ordinário da Faculdade de Direito de São Paulo".

51 RANGEL, Vicente Marotta. (pref. cit., 1980, p. viii); RANGEL, Vicente Marotta. (art. cit., 1992, p. 308).

52 RANGEL, Vicente Marotta. (pref. cit., 1980, loc. cit.).
} 
“O direito está para o organismo social”, dizia José Mendes (1913), ${ }^{53}$ “como a veste para o organismo individual : um e outro acompanham o desenvolvimento do respectivo corpo. Cada fase da evolução social contém a fase anterior, com alguma coisa a mais. Cada fase é o resumo das fases anteriores, numa e noutra evolução", retomaria J. Mendes (1918). ${ }^{54}$

José Mendes apontava com discernimento o papel a ser desempenhado pelo Direito Internacional: “este ramo da árvore jurídica em formação, adaptado à sociedade internacional, Civitas Maxima, Societas Societatum, ora também em formação e cujas condições de vida e desenvolvimento exigem, como as da sociedade nacional, reconhecimento e garantias tendentes à manutenção do equilíbrio das espheras de actividade dos estados, unidades do organismo social mundial". ${ }^{55}$

Theophilo Benedicto de Souza Carvalho (nascido em 1869-? - ainda vivia em 1927), "exerce a advocacia em São Paulo" relata W. Ferreira (1928) ${ }^{56}$ foi nomeado professor catedrático de Direito Internacional Público e Privado, por decreto de 29 de maio de 1918, da qual tomou posse em 10 de junho seguinte. Sucede, assim, a José Mendes (1861-1918). ${ }^{57}$

${ }^{53}$ MENDES, José. Direito internacional público: prelecções. São Paulo: Duprat \& Comp., 1913, 'prefácio', datado de 15 de novembro de 1913: "Este livro reflecte em synthese as minhas prelecções de Direito Internacional Público, na Faculdade de Direito de São Paulo. / Transumpto da explicação de todas as theses de meu programma, traz a nomenclatura de todas as questões de mais destaque no assumpto, discutidas e resolvidas durante o curso. / Contém as linhas essenciaes dos institutos jurídico-mundiaes, sem descer a detalhes, consoante já aconselhavam os Estatutos da Universidade de Coimbra de 1772. / A linguagem é simples, conforme o salutar exemplo dos modernos expositores da matéria scientífica. Sciencia e rhetorica são coisas que se não attraem. ORNARI RES IPSA VETAT, CONTENTA DOCERI."

${ }^{54}$ MENDES, José. Relação entre o direito internacional público e o direito nacional nos países americanos (18 RT 81 (1918)).

${ }^{55}$ MENDES, José. op. cit., 1913, 'prefácio’ cit.; encerrava-o: "É, pois, um manual de estudantes. Escrevel-o custou-me grande somma de exforços, a que me não poupei, cônscio do intento de satisfazer a uma necessidade vivamente sentida e repetidamente manifestada por meus discípulos, a cujas mãos o entrego, certo de que farão delle um dos factores do progresso de nossa cultura jurídico-internacional."

${ }^{56}$ FERREIRA, W. op. cit., 1928, p. 116: "Inscreveu-se em vários concursos abertos na Faculdade de Direito de São Paulo, em 1897, em 1902, em 1909, em 1910 e 1911. Disputou a livre-docência em 1911 e a obteve em 28 de outubro de 1914 com o Dr. Manoel Aureliano de Gusmão. Neste mesmo ano, por decreto de 20 de outubro, foi nomeado professor extraordinário efetivo da primeira seção. Tomou posse em 28 do mesmo mês, recebendo o grau de doutor".

${ }^{57}$ Sobre o autor veja-se: COSTA, José da Silva. Carta do eminente jurisconsulto. In: Ensaios de filosofia do direito. São Paulo: Duprat, 1905; VAMPRÉ, Spencer. Memórias para a história da Academia de São Paulo. 2. ed. Brasília: INL, 1977. p. 427-429; CENTRO DE DOCUMENTAÇÃO DO PENSAMENTO BRASILEIRO (Org.). op. cit., p. 317-318; registra a respeito de José Mendes: "Nasceu no interior de Minas Gerais, a 27 de março de 1861. Diplomou-se pela Escola Normal de Campanha, dedicando-se ao magistério secundário. Mais tarde transferiu-se para São Paulo, matriculando-se na Faculdade de Direito, bacharelando-se em 1891. Passou, então, a advogar no interior paulista (Mococa). Em 1911 ingressou no corpo docente da Faculdade, onde chegou a catedrático e teria a oportunidade de reger a cadeira de Filosofia do Direito (?). Foi membro fundador do Instituto dos Advogados de São Paulo. Morreu assassinado em Mococa, a 28 de março de 1918, aos 57 anos". A bibliografia de José Mendes incluem, ainda, Servidões de caminho (São Paulo, s/d), e Ensaios 
Em 1918 pela primeira vez, o ensinamento de Direito Internacional, na Faculdade de Direito de São Paulo cinde-se em: Direito Internacional Público, $1^{\mathrm{a}}$ cadeira do $2^{\circ}$ ano, "apresentado pelo professor cathedratico Dr. José Mendes e adotado para o ano de 1918 pelo professor doutor Theophilo B. de Souza Carvalho", enquanto o "programa de ensino de Direito Internacional Privado, $5^{\mathrm{a}}$ cadeira do $5^{\circ}$ ano", foi igualmente apresentado pelo mesmo catedrático, Dr. José Mendes.

A Souza Carvalho caberá dar prosseguimento ao ensino do Direito Internacional Privado até 1938. Nesse mesmo ano, consta menção ao "programa do Prof. Dr. Theophilo B. de Souza Carvalho, adotado pelo Prof. Dr. Antonio de Sampaio Dória".

Concomitantemente a Souza Carvalho, desenvolver-se-á o trabalho de Braz de Souza Arruda, como regente de "Direito Público Internacional", este a partir de 1921. Não é mero detalhe terminológico a inversão da ordem dos termos, porquanto nesta configuração se enfatiza o caráter de Direito Público, ou seja, emanado do estado, e projetado para o âmbito internacional, mas que Direito Internacional, propriamente dito. O que deve ser evitado, porquanto o priva de sua dimensão intrínseca e necessariamente internacional.

Poucos devem saber que Antonio de Sampaio Dória lecionou Direito Internacional Privado, em nossa escola. ${ }^{58}$ Aprovado em concurso para substituto da segunda seção da Faculdade de Direito de São Paulo, em 1919, foi nomeado livre-docente de Direito Público e Constitucional e de Direito Internacional Público e Privado. Aberta a vaga de professor catedrático de Direito Público e Constitucional, "pelo ter sido posto em disponibilidade o Dr. Herculano de Freitas", inscreveu-se o obteve o primeiro lugar. A partir daí consolidar-se-á a trajetória de Sampaio Dória na sua área específica.

Os nomes de Sampaio Dória e de Braz de Souza Arruda permanecem, lado a lado, até 1945 .

Braz de Souza Arruda (1895-?), ${ }^{59}$ foi nomeado professor catedrático de Direito Público Internacional por decreto de 6 de maio de 1925, tomando posse da cadeira em 14 do mesmo mês. ${ }^{60}$ Braz Arruda vangloriava-se ter sido o primeiro a tratar do Direito

de filosofia do direito (São Paulo : Duprat, 1905), além de seu já referido Direito internacional público (1913).

${ }^{58}$ A respeito deste, refere FERREIRA. Waldemar. op. cit., 1928, p. 130-131: matriculou-se em 1904, bacharelouse em 1908 na Faculdade de Direito de São Paulo.

${ }^{59}$ FERREIRA, Waldemar. op. cit., 1928, p. 124; a respeito de Braz de Souza Arruda: matriculou-se em 1912, bacharelou-se em 1916. Em 1917, prestou concurso e foi aprovado, por unanimidade de votos. Foi nomeado livre-docente, por portaria de 2 de maio de 1919 , tomando posse na mesma data. Por decreto de 23 de junho de 1920, aprovado em novo concurso, foi nomeado professor substituto da segunda seção, tomando posse em 5 de julho, quando recebeu o grau de doutor.

${ }^{60}$ FERREIRA, Waldemar. (op. cit., 1928, loc. cit.): "É o mais jovem dos professores da Faculdade de Direito de São Paulo. / Operoso, tem publicado vários trabalhos jurídicos na Revista da Faculdade de Direito de São Paulo, v. 21 e 22, e, em volume, editou as suas dissertações de concurso, em 1919." 
aeronáutico no Brasil. Pode-se questionar quanto de seu "Direito Internacional na era atômica" (s/d) ${ }^{61}$ efetivamente o seria - pois a bibliografia não seria a mais atualizada, disponível à época ${ }^{62}$. Foi também diretor da escola e leva seu nome a Biblioteca Circulante.

Em 1939 e 1940, ao lado da regência da cadeira de "Direito Público Internacional”, por Brás de Souza Arruda, apresenta-se o “programa de Direito Internacional Privado" do livre-docente prof. Manuel Francisco Pinto Pereira.

Para M. F. Pinto Pereira (1920), ${ }^{63}$ "o nosso século, que ao ius inter gentes há de traçar liames mais estreitos, muito terá caminhado si conseguir uma obediencia mais efficaz àquele velho princípio fundamental do direito, que é a base universa de quaisquer normas jurídicas. O ideal dos indivíduos, para o qual convergem todas as forças, é a realisação do direito; como também essa realisação é o ideal mais alto, à volta do qual, nas relações internacionaes, os esforços das gentes se intensam.

A sociedade mundial, organizada politicamente, acresce dimensão de Direito Internacional positivo a esses pressupostos conceituais da igualdade e das regras básicas de convivência entre os estados, no plano internacional:64 "organisar o mundo, numa só sociedade politica, é o mais complexo problema, que a mente humana tem concebido, já pela connexão com mil outros difficilimos problemas, já pela chocante desharmonia de outros tantos. É verdade que, nos povos civilisados, são muitas as convergencias de ideaes; não o é menos, todavia, que as divergencias são muitissimas". ${ }^{65}$

\footnotetext{
${ }^{61}$ ARRUDA, Braz de Souza. Curso de direito internacional: na era atômica. Curitiba / São Paulo / Rio de Janeiro: Ed. Guaíra Ltda., s/d - mas, no 'cavaco', p. 5-11, refere ter completado "25 anos de cátedra em 1945!", cit. pp. 7-8) : "No volume 23 da revista da Faculdade vem o resumo das minhas prelecções de Direito Internacional, onde se vê que fui o primeiro a tratar entre nós do direito aéreo e da radiofonia, em suas projecções no campo do direito".

${ }^{62}$ Quero encontrar a resenha de G. E. do Nascimento e Silva publicada por ocasião da publicação do (ARRUDA, Braz de Souza. Curso de direito internacional: na era atômica. Curitiba / São Paulo / Rio de Janeiro: Ed. Guaíra Ltda., s/d), na qual este referia que o livro embora voltado ao Direito Internacional na era atômica utilizava bibliografia predominantemente do século anterior !

${ }^{63}$ PEREIRA, M. F. Pinto. Soberania das nações. Prefácio de Clóvis Bevilaqua. São Paulo: C. Teixeira \& Cia., 1920.

${ }^{64}$ Id. Ibid. (par. 50, 'a sociedade mundial, organisada politicamente', p. 28-39): "Da simples sociedade das nações, que é o seu convívio sob o Direito Internacional, à organisação política da sociedade mundial, vae irreductivel differença. Dissemos : non gentium societas supremae uniuscujusque potestatis negatio implicet, plena ejusdem, autem affirmatio. / Mas, com a organisação política da sociedade mundial, sob a fórma da 'Liga das Nações', impossível é conciliar-se a permanencia da soberania nacional. Aquella organisação, com ser política, necessariamente, implica a idéia de um governo universalmente obedecido".

${ }^{65}$ Id. Ibid. (cap. cit., p. 29, a seguir, p. 35, e, mais adiante, p. 39): "A organisação política da Sociedade das Nações, numa Liga, é um pensamento que não se ajusta com a realidade. Muitos são os mestres que o nutrem; mas, contrariadas pela experiencia, 'as autoridades não valem a menor prova de facto'.. (...) "A soberania nacional permanecerá. Com ella é difficilimo o exito da 'Liga das Nações' e absolutamente impossível conciliar-se a organisação política da sociedade mundial”.
} 
Dado ser inexorável o imperativo da convivência, a organização desta acarretará limitar o conceito e a extensão do exercício da soberania de cada estado, já percebia M. F. Pinto Pereira (1920): “o estado melhor organisado jamais lograra independencia absoluta, a menos que se isolasse do convivio mundial, e, nesse caso, a sua sorte seria fatalmente o anniquilamento. A comunidade das nações força-as a se darem reciprocamente as mãos e a se fazerem concessões recíprocas ; embora em differentes situações políticas, conduz as poderosas a coadjuvarem, no quanto possível, as que o não são. Outro não é o ensinamento dos mestres. (...) Como, apezar do crescente progresso humano, já tantas vezes os interesses vitaes dos povos soberanos se chocaram, ferindo-se guerras, não tenhamos a ingenuidade de descrer que isso possa repetir-se ; repetir-seá, porém, com menor frequencia, si se temperar o conceito de soberania nacional pelo princípio salutar da solidariedade das nações". ${ }^{66}$

Voltam a aparecer, respectivamente, os nomes de Braz Arruda e Sampaio Dória, em 1941, e assim permanecem, até 1945.

Em 1946, permanece Braz arruda e ao lado deste, para o Direito Internacional Privado "programa do Prof. Dr. Antonio de Sampaio Dória adotado pelo livre-docente Dr. L. A. da Gama e Silva". ${ }^{67}$ Repete-se a formulação, de 1948 até $1952 .{ }^{68}$

De 1955 até 1963, os programas de Direito Internacional Público e Privado serão apresentados, respectivamente, por Braz Arruda e Gama e Silva. Em 1964 e 1965 , em relação ao Direito Internacional Público, consta o "programa do Prof. Braz de Souza Arruda, adotado pelo Dr. Vicente Marotta Rangel, na regência da cátedra" . ${ }^{69}$ De 1966 em diante este regerá a cátedra de Direito Internacional Público.

\footnotetext{
${ }^{66}$ PEREIRA, M. F. Pinto. Soberania das nações. Prefácio de Clóvis Bevilaqua. São Paulo: C. Teixeira \& Cia., 1920. p. 45-46, e prossegue, p. 46-47: "A idéia da comunhão do direito, agitada por Savigny no campo do Direito Internacional privado, e que é hoje um pensamento quase universal, assaz pode concorrer para as solidarisar. É mister que os paizes cultos cooperem para cimentar a sua grande communidade, regida, quando possível for, pelo direito pacifico. / Isso não obsta, bem o vemos, a que a cada qual fique a sua soberania, e como attributo essencial : o que se quer é que ella seja comparticipe activa da solidariedade de todos, na pratica da equidade e da justiça, para a realisação do maior bem commum. A cooperação das grandes e pequenas nações, soberanas e egualmente solidarias, não pede que na vida particular ellas ajam, umas exactamente conforme as outras. / A societas gentium é o ponto em que se hão de converter no bem estar da humanidade os contingentes do trabalho nacional de cada povo. Si circunstancias peculiares vigem, no sentido da differenciação intranacional dos estados, a vida internacional tende a semelhal-os, pela conjugação dos esforços communs em prol de todos. Eis o terreno da cooperação; ella 'supõe a diversidade de meios e simplesmente harmonia de fins'. / A verdadeira solidariedade das nações soberanas consiste no promoverem, sobre tudo, a justiça nas suas relações, obedecidas as sentenças dos tribunaes, que proclamam o direito, tendose a força armada como o extremo recurso no solucionar das pendências".

${ }^{67}$ Não há exemplar de Anuário para 1947.

${ }^{68}$ Não há exemplar de Anuários para 1953 e 1954.

${ }^{69}$ Não há exemplar de Anuário para 1967. V. QUEIROZ FILHO, Manoel Elpídio Pereira de. Faculdade de direito / Largo de São Francisco: turmas de 1949, 1950 (turma do Ano Santo), 1951 e Agregados - Espírito acadêmico, tipos, picardias e estudantadas. São Paulo: Faculdade de Direito, (C) desta edição 2009, no capítulo 'Turma do diretor - o professor Arrudinha', p. 103-107) a respeito: "O Arrudinha, nosso querido mestre e
} 
Na cátedra de Direito Internacional Privado, Gama e Silva, ${ }^{70}$ depois de a exercer por vinte anos, será também o diretor da escola, e ministro da justiça. ${ }^{71}$ Não será freqüente ouvirem menção ao nome de Gama e Silva.

Será este sucedido por Irineu Strenger (1923-2007), que, por sua vez, a exercerá por vinte anos, de 1971 a $1991 .^{72}$ Imaginem o ministro da justiça do mais sombrio período do regime militar, ao qual se atribui a redação do nefando "ato institucional n. 5" ser sucedido por ex-militante de esquerda? Em meio à tensão, então reinante, às vésperas do concurso as "autoridades administrativas" requisitaram a presença de Irineu Strenger, que, liberado, chega a tempo para terminar o concurso e conquistar a cátedra de Direito Internacional Privado.

Nessa mesma cadeira de Direito Internacional privado, Strenger será sucedido por João Grandino Rodas, nosso atual diretor. ${ }^{73}$

patrono da turma de 50 , nosso professor no $4^{\circ}$. ano, era estourado. Todos, catedráticos, alunos e funcionários, tinham medo dele. Quando explodia era um Deus-nos-acuda. Diziam as más línguas que era doido varrido".

${ }^{70}$ SILVA, Luís Antonio da Gama e As qualificações em direito internacional privado. 1952. Monografia (Concurso à cátedra) - Faculdade de Direito, Universidade de São Paulo, São Paulo.

71 No período militar do nefando "AI-5", de triste memória, e advertência para todos os cultores do direito.

72 STRENGER, Irineu. Teoria geral do direito internacional privado. São Paulo: José Bushatsky, 1973; Arbitragem comercial internacional. São Paulo: LTr, 1996; Prefácio. In: CASELLA, Paulo Borba. Comunidade européia e seu ordenamento jurídico. 2. ed. São Paulo: LTr, 1994, 2002; . Temas de formação filosófica. São Paulo: Revista dos Tribunais, 1986. 158 p.; . Da autonomia da vontade em direito internacional privado. 1967. 230 p. Tese (Livre-docência) - Faculdade de Direito, Universidade de São Paulo, São Paulo.; depois publicada, com o mesmo título pela Editora Revista dos Tribunais em 1968; . Regime jurídico da reparação do dano em direito internacional privado. 1971. 275 p. Tese (Titular) - Faculdade de Direito, Universidade de São Paulo, São Paulo.; depois publicada, Reparação do dano em direito internacional privado. Prefácio de Amílcar de Castro. São Paulo: Revista dos Tribunais, 1973;

. Direito internacional privado: parte geral, direito civil internacional, direito comercial internacional. $\overline{1 . \text { ed. }}$. São Paulo: Revista dos Tribunais, 1986; (4. ed., aumen. e atual. São Paulo: LTr, 2000); . Mandado de injunção. Prefácio de J. Cretella Jr. Rio de Janeiro: Forense Universitária, 1988; Irineu Strenger foi responsável pela revisão terminológica da tradução do volume (LESGUILLONS, Henry (Org.). As garantias bancárias nos contratos internacionais. São Paulo: Saraiva / FEDUCI, 1985; Direito moderno em foco. São Paulo: Revista dos Tribunais, 1986. prefácio: “O direito moderno em foco é, precisamente, captação dos principais elementos que hoje conduzem o direito a novos rumos, em vários campos da fenomênica jurídica, entre os quais despontam os temas da responsabilidade civil, o direito marítimo, e alguns importantes aspectos legais do dinheiro, tão bem assinalados por Paulo Borba Casella, cuja contribuição se encontra em anexo deste livro"; . Contratos internacionais do comércio. Prefácio L. G. Paes de Barros Leães. 1. ed. São Paulo: Revista dos Tribunais, 1986 (2. ed., rev. e ampl., 1992); BAPTISTA, Luis Olavo; HUCK, Hermes Marcelo; CASELLA, Paulo Borba (Orgs.). Direito e comércio internacional: tendências e perspectivas - estudos em homenagem a Irineu Strenger. São Paulo: LTr, 1994; STRENGER, Irineu. La notion de lex mercatoria en droit du commerce international. Recueil de Cours de l'Académie de Droit International, Haye, n. 227, p. 207356, 1991; e também, . Direito do comércio internacional e lex mercatoria. Prefácio Fábio Konder Comparato. São Paulo: $\overline{\mathrm{LTr}, 1996 .}$

${ }^{73}$ RODAS, João Grandino; MONACO, Gustavo Ferraz de Campos. Conferência da Haia de direito internacional privado: a participação do Brasil. Brasília: FUNAG, 2007; RODAS, João Grandino; OLIVEIRA, Gesner. Direito e economia da concorrência. Rio de Janeiro: Renovar, 2004; RODAS, João Grandino (Coord.). Contratos internacionais. 3. ed. São Paulo: Revista dos Tribunais, 2002; RODAS, João Grandino. Sociedade comercial e estado. Prefácio Fábio Konder Comparato. São Paulo: UNESP / Saraiva, 1995; RODAS, João 
3. Enfoque conceitual de fenômenos recentes à luz do Direito Internacional

A questão da condição de sujeito de Direito Internacional, suscita questões sobre o começo e o fim da personalidade internacional (tanto em relação a estados como organizações internacionais, e aos assim chamados "agentes não-estatais", no plano internacional - o modelo ainda não acolhe de maneira consistente as novas manifestações de personalidade internacional). Os meios de fazer assegurar a assunção, a cessão e a extinção de direitos e de obrigações no plano internacional ainda é objeto de controvérsias.

Mostra-se, claramente, a passagem da bilateralitdade rumo à institutionalização da multilateralidade como marca característica da ordenação e base operacional do sistema internacional: onde se inscrevem, também as mutações, com relação a matérias ditas novas no conjunto do Direito Internacional pós-moderno. A aparente fluidez da prática e a diversidade dos caminhos adotados não escondem grandes linhas, que podem ser anunciadas: as normas não são aleatórias; as normas podem ter certo grau de flexibilidade, em sua implementação, mas não será por isso que estas deixam de existir ou perderiam a sua condição de juridicidade; existe interesse comum ou de ordem coletiva, enquanto dado para orientar os diferentes casos, do ponto de vista do conjunto dos estados e das organizações internacionais; as organizações internacionais financeiras se engajaram em preservar direitos e obrigações, de modo a assegurar a continuidade operacional e a liquidez do sistema financeiro internacional - embora eventos recentes mostrem quanto ainda é incipiente essa coordenação.

Se, na crucial questão do acesso às armas nucleares, reina a seletividade na aceitação 'controlada' do acesso a esta - onde, para preservar o status quo alguns instrumentos foram criados, tais como o Tratado de não-proliferação nuclear (TNP) vale, contudo, ressaltar se ter assegurado alguma indispensável efetividade e continuidade ao regime legal internacional, vigente na matéria.

Como direcionar o enfoque conceitual dos grandes temas, em Direito Internacional permite determinar critérios e parâmetros, ante a aparente diversidade: a prática consagra a volatilidade, que se exprime pela intransferabilidade de tratados políticos, tais como os de aliança militar, de neutralidade ou de assistência recíproca entre estados. No sentido inverso, são considerados como tratados que permanecem em vigor, segundo

\footnotetext{
Grandino. A nacionalidade da pessoa física no Brasil, após 1988. In: BAPTISTA, Luis Olavo; HUCK, Hermes Marcelo; CASELLA, Paulo Borba (Orgs.). Direito e comércio internacional: estudos em homenagem ao prof. Irineu Strenger. São Paulo: LTr, 1994. p. 221-241; RODAS, João Grandino. Direito internacional privado brasileiro. São Paulo: Revista dos Tribunais, 1993; RODAS, João Grandino. Choice of law rules and the major principles of Brazilian private international law. In: DOLINGER, Jacob; ROSENN, Keith (Ed.). A panorama of Brazilian Law. Miami / Rio de Janeiro: Univ. of Miami North-South Center / Ed. Esplanada, 1992. p. 309-347; RODAS, João Grandino. A nacionalidade da pessoa física. São Paulo: Revista dos Tribunais, 1990.
} 
o Direito consuetudinário, e como necessidade operacional do Direito Internacional em vigor, no caso dos tratados multilaterais normativos - como expressão de dados basilares, de interesse comum da comunidade internacional.

C. W. Jenks $(1973)^{74}$ enfatizava o sentido das "obrigações, que decorrem de tratados normativos, são, antes obrigações legais que obrigações contratuais" onde "novo membro da comunidade internacional estará vinculado pelas normas do Direito Internacional costumeiro" - e essas normas são em considerável medida expressão do Direito Internacional positivo.

\subsection{Questão do dia e temas gerais}

Poucas ocasiões sem ver aplicados conceitos e métodos de Direito Internacional, mas refletem escolhas políticas e os esforços de consolidação de normas de Direito Internacional. Não somente aplicadas enquanto Direito Internacional Positivo, mas também lembrado enquanto conjunto de normas e parâmetros de regulação da matéria.

A codificação do Direito Internacional, por meio de relevante conjunto de Convenções adotadas e instituições internacionais criadas nas últimas décadas mudam substancialmente a realidade e os métodos de ensino do Direito Internacional desde 1960 - por ironia do destino, serão justamente os novos estados, surgidos da descolonização que marcam o Direito Internacional pós-moderno: aumento do número de participantes, complexidade crescente das negociações internacionais, ampliação exponencial da agenda de relevância e de necessidades internacionalmente compartilhadas entre os estados : de temas clássicos como a cooperação judiciária internacional, cada vez mais presentes, em matérias específicas como a luta contra o crime organizado, a repressão ao terrorismo, a novas dimensões de internacionalidade intrínseca, da proteção internacional dos direitos fundamentais à proteção ambiental internacionalmente organizada.

O aumento do número e da diversidade dos interlocutores torna ainda mais necessários os mecanismos de composição entre estes. Esse dado é crucial, para a compreensão do Direito Internacional do tempo presente.

Ao lado desse movimento, outro não menos relevante, de reconhecimento progressivo de jus cogens internacional, e de obrigações erga omnes sem negligenciar a resistência dos estados, diante de modelo que os transcenda como sujeitos determinantes para o surgimento de qualquer norma internacional - mesmo que estes permaneçam indispensáveis como operadores do sistema institucional e normativo - a teoria do

${ }_{74}$ JENKS, C. W. Economic and social change and the law of nations. Recueil de Cours de l'Académie de Droit International, Haye, n. 138, p. 455-502, 1973. 
desdobramento funcional de Georges Scelle (1936) ou, entre nós Celso D. de Albuquerque Mello (2004).

Após 1989 se produz nova mutação institucional e operacional no sistema internacional, com o fim da guerra fria - torna-se obsoleta toda a doutrina excessivamente engajada (mostra-se o vazio da tentativa de construção, na antiga União soviética de modelo 'não-burguês' de Direito Internacional), o vazio intelectual e político, ensejam década de considerável progresso no funcionamento das instituições internacionais (operações de paz da ONU e avanços institucionais relevantes, como o Tribunal Penal Internacional, cf. Estatuto de Roma, de 1998).

Nos anos 1990 : após o fim de quatro décadas de confrontação no plano da guerra fria, se instaura nova fase de vida e de funcionamento do sistema institucional e normativo internacional: haverá predominância da flexibilidade e da adaptabilidade no conjunto da matéria do Direito Internacional.

Uma década excelente (1990-2000) em termos de funcionamento eficaz das instituições internacionais, é seguida por outra, quase década (2000-2008), com registro lamentável em relação a se acreditar no papel e no futuro do Direito Internacional - invasões do Afeganistão, desde 2001, e do Iraque, desde 2003, artifícios interpretativos para tornar 'legal' a prática da tortura de prisioneiros de guerra, aos quais se negam tanto as garantias das Convenções de Genebra, de 1949, como as emanadas do Direito Constitucional americano, e assim vai.

É alvissareiro para os EUA e para o mundo que estes deixem de ser país 'fora da lei' internacional: o gesto de B. H. Obama de mandar fechar a base militar de Guantánamo e declarar que os EUA estão obrigados a aplicar as Convenções de Genebra mostram que a matriz da formação humana e jurídica estadunidense, apesar de decadente, como aponta J. Dolinger (2008), ${ }^{75}$ ainda é passível de reprisitinação, quiçá de aperfeiçoamento.

Há necessidade de se olhar mais adiante: os progressos no conhecimento humano se fazem na medida em que tenham lugar a análise crítica e as dúvidas sejam confrontadas. E isso se aplica e se percebe, igualmente, entre nós.

Se, de um lado, andamos bem e tivemos o ensino do Direito Internacional desde literalmente o primeiro dia de funcionamento dos cursos jurídicos no Brasil, e isso mesmo antes de muitas universidades estrangeiras, à mesma época, por outro lado, nem sempre andamos bem desde então. Podem ser apontados alinhamentos no sentido de 'nacionalização' do Direito Internacional, no sentido de alinhamento prioritários, segundo

\footnotetext{
${ }^{75}$ DOLINGER, Jacob. Os Estados Unidos perante o direito internacional: a decadência jurídica de uma grande nação. In: Novas perspectivas do direito internacional contemporâneo: estudos em homenagem ao prof. Celso D. de Albuquerque Mello. Rio de Janeiro: Renovar, 2008. p. 83-134.
} 
interesses nacionais e momentâneos', de modo semelhante ao que se fez em outras praças, mas que privam o Direito Internacional de sua dimensão verdadeira, tautologicamente internacional, como de seu conteúdo humano, que é indispensável manter, como foco e centro: ainda se questiona o reconhecimento do ser humano como sujeito de direito, no plano internacional - muito embora este já seja reconhecido como sujeito de obrigações, no mesmo plano, pelo Direito Internacional Penal. Esses males devem ser apontados, por não ser somente desvio de rumo do passado, mas perigos recorrentes, contra o espírito e o propósito da disciplina.

Pouco nos há de alegrar, ademais, o fato de que o ensino do Direito Internacional, nos cursos jurídicos do Brasil, ${ }^{76}$ ter sido relegado a posto secundário e 'optativo', no currículo mínimo dos cursos de Direito, ${ }^{77}$ durante a assim chamada "flexibilização", ocorrida no período de 1972 a $1994 .{ }^{78}$ Ainda se colhem os (maus) frutos dessa escolha equivocada. Até ser substituída pela Portaria 1886/94/MEC, ${ }^{79}$ que instaura o regime aplicável, a partir de 1994, quando retorna à obrigatoriedade o ensino do Direito Internacional nos cursos jurídicos nacionais. ${ }^{80}$

Foram necessários mais de vinte anos, praticamente o espaço de vida útil de uma geração, para voltar o Direito Internacional a ser parte do currículo mínimo

${ }^{76}$ RODRIGUES, Horácio Wanderlei. Novo currículo mínimo dos cursos jurídicos. São Paulo: Revista dos Tribunais, 1995. esp. cap. 1, 'ensino jurídico no Brasil: balanço geral', p. 9-39) contém breve relato histórico.

77 Id. Ibid., cap. 2, 'o currículo e suas reformas, na história do ensino jurídico brasileiro', p. 40-61. Nos anos de 1972 a 1994, boa parte dos cursos de graduação em Direito, seguindo a diretriz da Resolução 3/72/CFE, de 25 de fevereiro de 1972, emanada do Conselho federal de educação, manteve o Direito Internacional público ou Direito Internacional privado, como duas escolhas possíveis, dentre leque das matérias optativas.

${ }^{78}$ Resolução 3/72/CFE : O presidente do Conselho federal de educação, no uso de suas atribuições legais, na forma do art. 26, da Lei n. 5540, de 28 de novembro de 1968, e tendo em vista o parecer 162/72 (...) resolve : art. $1^{\circ}$. O currículo mínimo do curso de graduação em Direito compreenderá as seguintes matérias : (...) 1 a 11 (...) 12/13. "Duas dentre as seguintes : (a) Direito Internacional público, (b) Direito Internacional privado, (c) Ciência das Finanças e Direito Financeiro (tributário e fiscal), (d) Direito da navegação (marítima), (e) Direito Romano, (f) Direito Agrário, (g) Direito Previdenciário, (h) Medicina Legal, de elenco compreendendo, ainda, a exigência de "prática forense, sob a forma de estágio supervisionado" e "o estudo de problemas brasileiros e a prática de educação física, com predominância desportiva, de acordo com a legislação específica" etc.

79 Portaria 1886/94/MEC, art. 6”: “O conteúdo mínimo do curso jurídico, além do estágio, compreenderá as seguitnes matérias, que podem estar contidas em uma ou mais disciplinas do currículo pleno de cada curso. I - fundamentais: Introdução ao Direito; Filosofia (geral e jurídica); ética geral e profissional; sociologia (geral e jurídica); economia e ciência política (com teoria geral do estado); II - profissionalizantes: Direito Constitucional, Direito Civil, Direito Administrativo, Direito Tributário, Direito Penal, Direito Processual Civil Direito Processual Penal, Direito do Trabalho, Direito Comercial e Direito Internacional. Parágrafo único: as demais matérias e novos direitos serão incluídos nas disciplinas em que se desdobrar o currículo pleno de cada curso, de acordo com suas peculiaridades e com observância de interdisciplinariedade".

${ }^{80}$ RODRIGUES, Horácio Wanderlei. op. cit., 1995, cap. 3, 'a portaria 1886/94/MEC e o novo currículo mínimo dos cursos jurídicos', p. 62-93. 
'obrigatório': descobriram os burocratas universitários a importância deste ${ }^{81} \mathrm{E}$ a falta que faz para a formação do bacharel em Direito, no mundo globalizado?

Antes tarde do que nunca, se terá descoberto esta evidência. Consigne-se nunca se ter interrompido o ensino do Direito Internacional nesta casa. ${ }^{82}$

\subsection{A institucionalização do Direito Internacional}

Vicente Marotta Rangel, bacharel em Direito pela Faculdade de Direito da Universidade de São Paulo, em 1946, é doutor em Direito Internacional pela Universidade de Paris, em 1950.$^{83}$ Livre-docente em Direito Internacional, em 1955, com tese Do conflito entre a Carta das Nações Unidas e os demais acordos internacionais (1954), ${ }^{84}$ torna-se catedrático de Direito Internacional Público, em 1966, com tese sobre Natureza jurídica e delimitação do mar territorial (1964, 2. ed., rev., 1970). ${ }^{85}$

Marotta Rangel regerá a cátedra de 1966, até aposentar-se em 1994. Foi, também, durante quatro anos, diretor desta Faculdade. Ministrou curso na Academia de Direito Internacional, na Haia, sobre A plataforma continental na Convenção de 1982 sobre o direito do mar (1985). ${ }^{86}$ A sua extensa e relevante produção ${ }^{87}$ se soma o papel

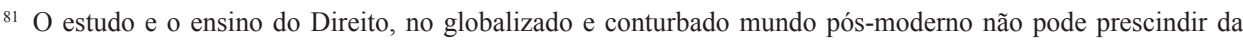
formação em Direito Internacional: parecem ter se dado conta disso - e essa necessidade se faz sentir junto ao mercado e pelo mercado, com a mudança considerável da percepção da necessidade e do papel das disciplinas do Direito Internacional, se considerarmos período histórico relativamente curto, como os últimos vinte e cinco anos : de interesse minoritário, como historicamente se manteve, passa a ter procura ampliada e suscitar interesse renovado, junto aos estudantes. É fundamental que essas possíveis vocações sejam, primeiro, bem formadas e, a seguir, bem orientadas.

${ }^{82}$ Fazia questão de o frisar Geraldo Eulálio do Nascimento e Silva, ter sido graças ao empenho de V. Marotta Rangel, durante os quase trinta anos em que regeu esta mesma cátedra, de 1966 até 1994, nunca se ter deixado de ensinar Direito Internacional nas Arcadas!

${ }^{83}$ Auxiliar de ensino em 15 de setembro de 1954; livre-docente em 28 de junho de 1955; professor assistente contratado em $1^{\circ}$ de janeiro de 1960; professor assistente nomeado em 26 de março de 1965; rege a cadeira, interinamente, bem como o curso de organizações internacionais a partir de outubro de 1965. Acede à cátedra em 1966.

${ }^{84}$ RANGEL, Vicente Marotta. Do conflito entre a Carta das Nações Unidas e os demais acordos internacionais. São Paulo: Saraiva, 1954.

${ }^{85}$ Id. Natureza jurídica e delimitação do mar territorial. 2. ed. rev São Paulo: Revista dos Tribunais, 1970.

${ }^{86}$ Id. Le plateau continental dans la Convention de 1982 sur le droit de la mer. Recueil de Cours de l'Académie de Droit International, Haye, n. 194, p. 273-427, 1985.
}

87 Id. Direito e relações internacionais. 8. ed. São Paulo: Revista dos Tribunais, 2005; L'avis consultatif du 9 juillet 2004 et l'antinomie entre volontarisme et solidarisme. In: International law and the use of force at the turn of centuries: essays in honour of V. Djuro DEGAN. Rijeka: Faculty of Law, Univ of Rijeka, 2005. cap. 10, p. 199-205; A experiência da conferência da ONU e a Convenção sobre direito do mar. In: NAZO, Georgette N. (Coord.). Questões importantes referentes ao mar. São Paulo: Soamar, 1996. p. 11-18; RANGEL, Vicente Marotta. Objetos culturais: o recente projeto UNIDROIT de convenção internacional. In: BAPTISTA, Luis Olavo; HUCK, Hermes Marcelo; CASELLA, Paulo Borba (Orgs.). Direito e comércio internacional: tendências e perspectivas - estudos em homenagem a Irineu Strenger. São Paulo: LTr, 1994. p. 213-220; RANGEL, Vicente Marotta. Sobre la efectividad de la justicia en las relaciones internacionales. 
destacado, no cenário nacional ${ }^{88}$ e internacional, como Juiz do Tribunal internacional para o Direito do mar, em Hamburgo, desde 1996, e o levaram a ser distinguido com os títulos de doutor honoris causa, pela Faculdade de Direito da Universidade de Coimbra, em 2000, bem como de professor emérito, concedido pela Congregação da Faculdade de Direito da Universidade de São Paulo, em 2006. ${ }^{89}$

Será sucedido V. Marotta Tangel, nessa cadeira, por Guido Fernando da Silva Soares (1937-2005). Este realiza seus estudos de "ciências jurídicas e sociais" na Faculdade de Direito da Universidade de São Paulo (1955-1959) e a seguir estudos de especialização (1960-1963) no Instituto Rio Branco, no Rio de Janeiro, para ingressar no serviço diplomático. Torna-se segundo secretário, em 1963, e serve nas Embaixadas do Brasil em Moscou e em Montevidéu.

Em 1970, retorna ao Brasil e ingressa no quadro docente da Pontifícia Universidade Católica de São Paulo, ao mesmo tempo em que enceta o doutorado em ciências humanas e a pós-graduação da Faculdade de Direito da Direito da Universidade de São Paulo. Cursa mestrado em Direito Comparado na Faculdade de Direito da Universidade de Illinois (1974-1975).

Doutora-se na PUC com a tese Contribuição ao estudo da política nuclear brasileira (1975) e é aprovado em concurso de livre-docência na Faculdade de Direito da USP, com tese sobre Das imunidades de execução e jurisdição (1980).

Em 1993 se vê reintegrado ao serviço diplomático. Vence concurso de titularidade para a cadeira de Direito Internacional Público, com tese sobre As responsabilidades no direito internacional do meio ambiente (1995), ${ }^{90}$ e toma posse da cadeira em 1998, da qual se afasta no final de 2004, e vem a falecer em 2005. ${ }^{11}$

In: El derecho internacional en un mundo en transformación: en homenaje al professor Eduardo Jimenez de Arechaga. Montevidéu: Fund. de Cultura Univ., 1994; RANGEL, Vicente Marotta. Public international law: the last five decades. In: DOLINGER, Jacob; ROSENN, Keith (Ed.). A panorama of Brazilian Law. Miami / Rio de Janeiro: Univ. of Miami North-South Center / Ed. Esplanada, 1992. p. 287-308; RANGEL, Vicente Marotta. L'equité en droit international: des développements récents. Tessaloniki: Aristoteleio Panepistimio «Nomos», «Anatypo»: separata, 1989, p. 937-950; RANGEL, Vicente Marotta. O direito do mar e a sua unificação legislativa entre países de língua portuguesa. In: Estudos em homenagem ao professor A. FerrerCorreia. Coimbra: Univ. de Coimbra, 1986. v. I, p. 69-90; RANGEL, Vicente Marotta. Solução pacifica de controvérsias. In: COMITÊ Jurídico Interamericano (Org.). XI Curso de derecho internacional. Cooperación de la Secretaria general de la OEA, Rio de Janeiro, agosto de 1984. Washington: O.E.A.- Secretaria General, 1985. p. 29-48.

${ }^{88}$ BAPTISTA, Luiz Olavo; FONSECA, José Roberto Franco da (Coords.). O direito internacional no terceiro milênio: estudos em homenagem ao professor Vicente Marotta Rangel. São Paulo: LTr, 1998. esp. p. 17-24, para as referências bio-bibliográficas).

${ }^{89}$ Há anos não concedia tal distinção a Congregação da Faculdade de Direito da Universidade de São Paulo.

${ }^{90}$ A tese de concurso de Guido Fernando da Silva Soares, foi publicada sob o título Direito internacional do meio ambiente: emergência, obrigações e responsabilidades. São Paulo: Atlas, 2001.

91 CASELLA, Paulo Borba; CELLI JUNIOR, Umberto; MEIRELLES, Elizabeth de Almeida; POLIDO, F, B. P. (Orgs.). Direito internacional, humanismo e globalidade: Guido Fernando Silva Soares Amicorum 
A Vicente Marotta Rangel coube aliar a pesquisa, docência e a experiência prática, como negociador brasileiro no Direito Internacional do Mar, e como Juiz do Tribunal internacional para Direito do mar. E prossegue, em sua atuação como docente, como juiz, e em sua produção intelectual.

A Guido Soares, por sua vez, coube atuar no segmento e contribuir para o desenvolvimento entre nós do Direito Internacional do Meio Ambiente, e neste deixar registro de sua relevante atuação.

Existe acervo relevante de produção nacional em Direito Internacional a ser resgatado. Esse trabalho encontra-se em curso.

De ponto de vista organizacional tornou-se esta antiga cadeira todo um departamento de Direito Internacional, e este tem caráter único, enquanto núcleo, institucionalmente organizado, de pesquisadores e docentes, no país, nas áreas do Direito Internacional Público, Direito Internacional Privado e Direito do Comércio Internacional. É preciso que se tenha consciência da importância desse conjunto, para que se pense e se opere como equipe, e não a mera somatória de projetos individuais paralelos.

Em razão da amplitude crescente como das dificuldades dos temas contidos em nossas disciplinas deu-se a progressiva institucionalização, no seio do que vem a ser, desde o início dos anos setenta, o Departamento de Direito International (DIN) da FDUSP, para preparar e adotar, em duas cadeiras que se somam à original, de Direito Internacional Público, destinadas ao ensino do Direito Internacional Privado e do Direito do Comércio Internacional, o conjunto das matérias que passam a compor o ensinamento de nosso departamento. Assim se mostra a percepção da necessidade do assunto, apesar das dificuldades, politicamente inerentes a seu tratamento jurídico, bem como a utilidade possível de estabelecer tais normas e quadros institucionais internacionais.

Em 2008, passa a ser o nosso "Departamento de Direito Internacional e comparado". Esta missão de ensinar o Direito Comparado se agrega ao conjunto, como proposta de ênfase na formação ampla e na perspectiva culturalmente abrangente, para a docência e a pesquisa destes campos do saber jurídico, sob nova direção.

Não se deixou simplesmente operar o costume, em relação ao ensino do Direito Internacional - houve escolhas, foram formuladas tentativas de sistematização dessas matérias, apesar do fato que as duas cadeiras e mais a terceira, de direito do comércio internacional, que às primeiras foi agregada, no início dos anos noventa, não cobrem todo o escopo do que se pode denominar "assuntos internacionais" e se cria, em separado, na USP, um instituto destinado ao ensino das assim chamadas "relações internacionais". Essas cadeiras expressam escolhas politicas e de gestão universitária - e isso apesar das objeções 
possíveis quanto à medida na qual sejam estas realemente representativas, enquanto objeto da codificação feita.

Conclusão

Longo o caminho percorrido pelo ensino do Direito Internacional em nossa Escola, desde a aula inaugural de Brotero em 1828, até o momento presente: o leque de matérias se amplia, a internacionalização da vida, no contexto pós-moderno sequer precisa ser enfatizada - todos percebem isso.

Considerar o Direito Internacional à luz do contexto pós-moderno significa inovar, no enfoque dado ao conjunto dos temas centrais da disciplina, contextualizado no mundo atual, ante a necessidade de responder ao desafio, que se põe para o direito como um todo, e se analisa em relação ao Direito Internacional. A pós-modernidade enfatiza a necessidade dos princípios, normas e procedimentos de Direito Internacional, não somente como ferramentas da paz e da segurança internacionais, mas como condições para a sobrevivência da humanidade, em mundo no qual a capacidade tecnológica de causar a destruição da vida e da civilização no planeta desenvolveu-se muito mais do que os mecanismos institucionais para garantir a paz : o quadro apresenta riscos e as ameaças são presentes e relevantes, mas a convicção da possibilidade de aperfeiçoamento das instituições e das normas internacionalmente indispensáveis. Estas são o modo melhor e mais seguro de garantir os fundamentos do Direito Internacional - para esta e as próximas gerações.

Cumpre ressaltar a necessidade da abrangência do enfoque e a pertinência da contextualização temporal e cultural, para o Direito Internacional, pelo caráter crucial de temas como a questão do uso da força, da construção dos princípios, da evolução da jurisprudência internacional, da codificação do Direito Internacional, e da consolidação das normas cogentes de Direito Internacional (jus cogens), bem como por situar a necessidade e o papel das instituições e do Direito Internacional, na ordenação das relações e da vida internacionais.

O Direito Internacional não pode ser visto nem tratado como disciplina puramente técnica : não tem caráter somente instrumental e não pode ser reduzido a isso. Tem dimensão intelectual e humana, a ser preservada, para que possa cumprir a sua missão precípua de construir bases para a comunicação e o diálogo entre os homens, como entre os colegiados humanos, sejam estes os estados, as organizações internacionais e os demais agentes do contexto internacional presente.

O estudo e o ensino do Direito das gentes, à luz de fatos recentes et da evolução do sistema institucional e normativo internacional nos mostram o caráter empírico dessa tradição, e a pouca clareza que pode existir em relação a quais sejam as regras que 
orientam a prática corrente, quais linhas mestras podem ser apontadas, quais lições podem ser tiradas, não somente como reflexão sobre o passado, mas como referências presentes e parâmetros para orientar ação futura?

A construção de escola de Direito Internacional nas Arcadas se fez ao longo destes 180 anos, transcorridos desde a lição inaugural de Avellar Brotero, em $1^{\circ}$. de março de 1828. As lições a serem extraídas dessa trajetória são múltiplas e são muito ricas.

Devem ser levadas em conta, pelos pósteros. ${ }^{92}$ Exatamente em 16 de fevereiro de 2009, na abertura do ano letivo e da semana de recepção aos calouros, se faz a apresentação deste estudo retrospectivo e prospectivo, Direito internacional nas Arcadas. O sentido da tradição, ressaltava O. Spengler (1923, nova ed., 2007), ${ }^{93}$ consiste, justamente em se ter consciência de que esta supere o dado fático inexorável do desaparecimento dos predecessores, mas que prossegue e congrega novos homens e correntes de ser, provindas das profundezas, nessa mesma corrente e impulso.

Ao mesmo tempo em que nos cumpre refletir sobre o legado dos que nos precederam, cabe ter presente a extensão das tarefas novas, onde se projetam os desafios e as necessidades para o Direito Internacional, no contexto da pós-modernidade. As situações mudam e as normas devem ser adaptadas a tais mutações, para refletir tais mudanças: mas isso não acarreta a mutação de todas as normas.

É dado humana e culturalmente compreensível o ensaio de construir a continuidade, face às situações de descontinuidade: aí se inscreve o ensinamento a respeito da necessidade e da operacionalidade do Direito Internacional - este existe e opera, mesmo quando confrontado com os desafios da prática - a continuidade se faz construir. Este existiu e operou em nossa escola, ao longo desses mais de 180 anos.

Dentre as mutações conceituais ocorridas desde então, a emergéncia das normas inderrogáveis no plano internacional, tais como a proteção dos direitos fundamentais: a tendência à continuidade se afirma como obrigação para todos os estados nos tratados multilaterais de proteção dos direitos fundamentais, e pode ser considerada como consolidada ao menos como princípios: a prática ainda sofre flutuações, mas se afirma a percepção objetiva dos tratados em matéria de Direitos Humanos como operando no absoluto: estes não conferem direitos às partes, mas tem por fim a instituição de normas

92 CASELlA, Paulo Borba. abz: ensaios didáticos. Prefácio de João Grandino Rodas. São Paulo: Imprensa Oficial do Estado, 2008: "Faculdade enquanto possibilidade - o papel do Largo de São Francisco"). Parte desse debate se fez e se faz no largo de São Francisco. Por isso pode ser relevante ter consciência do que representa a escola, para o país, e pode representar para a vida, de cada um dos que tem a oportunidade e a responsabilidade de participar dela.

93 SPENGLER, Oswald. Der Untergang des Abendlandes: Umrisse eine Morphologie der Weltgeschichte. (C) 1923. Düsseldorf: Albatroz, Neudruck, 2007. cit. p. 976: die Macht der Tradition nämlich die alte und feste Zucht, der sicher gewordene Takt von solcher Stärke, dass es das Absterben der alten Geschlechter überdauert und unaufhörlich neue Menschen und Daseinströme aus der Tiefe in seiner Bann zieht. 
comuns - traduzem valores compartilhados. ${ }^{94}$ Mesmo se permanece considerável margem para a apreciação dos estados, a institucionalização se põe claramente como tendência da evolução futura do Direito Internacional pós-moderno: adaptabilidade da aplicação não descaracteriza o conteúdo dos princípios institucionais.

Aí se inscreve programa de trabalho e a compreensão do papel da disciplina, cuja regência da cátedra me foi confiada: o Direito Internacional, no contexto pós-moderno, não pode deixar de ser internacional, no sentido de não se pautar somente pelas prioridades e pelas escolhas 'nacionais' - vimos os maus frutos disso, tanto fora como entre nós, mas, sobretudo, não se pode curvar aos ditames dos poderosos do momento, em detrimento de seu conteúdo humano. E de seu caráter humanista.

O que é o contexto da pós-modernidade? É a constatação da falibilidade dos modelos antes vistos como infalíveis, é a percepção da mortalidade da civilização, da fragilidade das construções do espírito humano, o alerta ao risco de retomada da barbárie, da pretensão do uso da força, como meio de imposição de uma vontade hegemônica, em detrimento da construção do diálogo. Constrói-se como sistema, e aperfeiçoa-se este sistema, como mecanismos normativos e procedimentais.

O Direito Internacional, do tempo presente, deve levar em conta a lição dos mestres do passado, não para retomar o que existia quanto estes escreveram - o que era, de ponto de vista institucional-normativo bastante incipiente - mas merece ser preservado ante o perigo de 'nacionalização' do Direito Internacional, como se tentou fazer, em determinadas épocas e quadrantes, em prejuízo do que seja o Direito Internacional e do papel que este possa ter na regulação da sociedade humana. Por isso a necessidade de consciência do papel que tem a desempenhar o Direito Internacional, em todas as sociedades humanas, sobretudo no tempo presente.

O mesmo propósito deve nortear o Direito Internacional em nosso contexto de crise de pós-modernidade. Porquanto as necessidades de ordenação da convivência social, bem como entre sociedades permanecem as mesmas. Mas aumentou a complexidade do mundo, no qual estas normas devem ser aplicadas.

São Paulo, fevereiro de 2009.

\section{Referências}

ARRUDA, Braz de Souza. Curso de direito internacional: na era atômica. Curitiba / São Paulo / Rio de Janeiro: Ed. Guaíra Ltda., s/d

\footnotetext{
${ }^{94}$ Como assinalava a Corte Internacional de Justiça no julgamento do caso Barcelona Traction (1970) "alguns direitos de proteção se integram ao Direito Internacional geral” (...) "outros são conferidos por instrumentos de caráter universal ou quase universal".
} 
AZEVEDO, Fernando de. A cultura brasileira: introdução ao estudo de cultura no Brasil. 4. ed. rev. e ampl. Brasília: Ed. UnB, 1963.

BAPTISTA, Luis Olavo; HUCK, Hermes Marcelo; CASELLA, Paulo Borba (Orgs.). Direito e comércio internacional: tendências e perspectivas - estudos em homenagem a Irineu Strenger. São Paulo: LTr, 1994

BAPTISTA, Luiz Olavo; FONSECA, José Roberto Franco da (Coords.). O direito internacional no terceiro milênio: estudos em homenagem ao professor Vicente Marotta Rangel. São Paulo: LTr, 1998.

BEVILAQUA, Clóvis. Prólogo. In: PEREIRA, M. F. Pinto. Soberania das nações. São Paulo: C. Teixeira \& Cia., 1920.

BROTERO, José Maria Avellar. Princípios de direito natural. Rio de Janeiro: Typographia Imperial Nacional, 1829

BROTERO, José Maria de Avellar. A filosofia do direito constitucional. Introdução de José Afonso da Silva. São Paulo: Malheiros, 2007.

BROTERO, José Maria de Avellar. Questões sobre presas marítimas. 2. ed. São Paulo: Typographia de Costa Silveira, 1836

BURDEAU, Georges. Sur un enseignement impossible. In: Mélanges offerts à Mr. le Doyen Trotabas. Paris: L.G.D.J., 1970.

CASELLA, Paulo Borba. abz: ensaios didáticos. São Paulo: Imprensa Oficial do Estado, 2008.

CASELLA, Paulo Borba. Direito internacional, vida e memória de Irineu Strenger (1923-2007). Revista de Arbitragem e Mediação, São Paulo, a. 4, n. 15, p. 11-18, out.-dez. 2007.

CASELLA, Paulo Borba. Fundamentos do direito internacional pós-moderno. Prólogo de Hugo Caminos. São Paulo: Quartier Latin, 2008.

CASELLA, Paulo Borba. ONU pós-KELSEN. In: MERCADANTE, Araminta de Azevedo; MAGALHÃES, José Carlos de. (Orgs.). Reflexões sobre os 60 anos da ONU. Ijuí: Ed. Unijuí, 2005. p. 13-64

CASELLA, Paulo Borba; CELLI JUNIOR, Umberto; MEIRELLES, Elizabeth de Almeida; POLIDO, F. B. P. (Orgs.). Direito internacional, humanismo e globalidade: Guido Fernando Silva Soares Amicorum Discipulorum Liber. São Paulo: Atlas, 2008.

CENTRO DE DOCUMENTAÇÃO DO PENSAMENTO BRASILEIRO (Org.). Dicionário biobibliográfico de autores brasileiros. Salvador: CDPB / Brasília: Senado Federal, 1999.

COSTA, José da Silva. Carta do eminente jurisconsulto. In: Ensaios de filosofia do direito. São Paulo: Duprat, 1905 
DOLINGER, Jacob. Os Estados Unidos perante o direito internacional: a decadência jurídica de uma grande nação. In: Novas perspectivas do direito internacional contemporâneo: estudos em homenagem ao prof. Celso D. de Albuquerque Mello. Rio de Janeiro: Renovar, 2008. p. 83-134.

ENKS, C. W. Economic and social change and the law of nations. Recueil de Cours de l'Académie de Droit International, Haye, n. 138, p. 455-502, 1973.

FACULDADE DE DIREITO DE SÃO PAULO. Memória histórica acadêmica de 1877. São Paulo: s.n., 1878 .

FERREIRA, Waldemar. A Congregação da Faculdade de Direito de São Paulo na centúria de 1827 a 1927 (separata da Revista da Faculdade de Direito de São Paulo, São Paulo : Typographia Siqueira, 1928).

KOSKENNIEMI, Martti. The gentle civilizer of Nations: the rise and fall of international law 18701960. Cambridge: University Press, 2001.

LESGUILLONS, Henry (Org.). As garantias bancárias nos contratos internacionais. São Paulo: Saraiva / FEDUCI, 1985

LOPES, José Reinaldo de Lima. O direito na história: lições introdutórias. 2. ed. São Paulo: Max Limonad, 2002.

MELO, Luís Correia de. Dicionário de autores paulistas. São Paulo: Comissão do IV Centenário da cidade de São Paulo / Serviço de Comemorações Culturais, 1954.

MENDES, José. Direito internacional público: prelecções. São Paulo: Duprat \& Comp., 1913

PEREIRA, M. F. Pinto. Soberania das nações. Prefácio de Clóvis Bevilaqua. São Paulo: C. Teixeira \& Cia., 1920.

PINTO, Antonio Pereira. Apontamentos para o direito internacional. Brasília: Ministério da Justiça / UnB, 1980.

QUEIROZ FILHO, Manoel Elpídio Pereira de. Faculdade de Direito / Largo de São Francisco: turmas de 1949, 1950 (turma do Ano Santo), 1951 e Agregados - Espírito acadêmico, tipos, picardias e estudantadas. São Paulo: Faculdade de Direito, (C) desta edição 2009.

RANGEL, Vicente Marotta. A experiência da conferência da ONU e a Convenção sobre direito do mar. In: NAZO, Georgette N. (Coord.). Questões importantes referentes ao mar. São Paulo: Soamar, 1996. p. $11-18$

RANGEL, Vicente Marotta. Direito e relações internacionais. 8. ed. São Paulo: Revista dos Tribunais, 2005

RANGEL, Vicente Marotta. Do conflito entre a Carta das Nações Unidas e os demais acordos internacionais. São Paulo: Saraiva, 1954. 
RANGEL, Vicente Marotta. L'avis consultatif du 9 juillet 2004 et l'antinomie entre volontarisme et solidarisme. In: International law and the use of force at the turn of centuries: essays in honour of V. Djuro DEGAN. Rijeka: Faculty of Law, Univ of Rijeka, 2005. p. 199-205

RANGEL, Vicente Marotta. L'equité en droit international: des développements récents. Tessaloniki: Aristoteleio Panepistimio «Nomos», «Anatypo»: separata, 1989, p. 937-950

RANGEL, Vicente Marotta. Le plateau continental dans la Convention de 1982 sur le droit de la mer. Recueil de Cours de l'Académie de Droit International, Haye, n. 194, p. 273-427, 1985.

RANGEL, Vicente Marotta. Natureza jurídica e delimitação do mar territorial. 2. ed. rev São Paulo: Revista dos Tribunais, 1970.

RANGEL, Vicente Marotta. O direito do mar e a sua unificação legislativa entre países de língua portuguesa. In: Estudos em homenagem ao professor A. Ferrer-Correia. Coimbra: Univ. de Coimbra, 1986. v. I, p. 69-90

RANGEL, Vicente Marotta. Objetos culturais: o recente projeto UNIDROIT de convenção internacional. In: BAPTISTA, Luis Olavo; HUCK, Hermes Marcelo; CASELLA, Paulo Borba (Orgs.). Direito e comércio internacional: tendências e perspectivas - estudos em homenagem a Irineu Strenger. São Paulo: LTr, 1994. p. 213-220

RANGEL, Vicente Marotta. Public international law: the last five decades. In: DOLINGER, Jacob; ROSENN, Keith (Ed.). A panorama of Brazilian Law. Miami / Rio de Janeiro: Univ. of Miami North-South Center / Ed. Esplanada, 1992. p. 287-308

RANGEL, Vicente Marotta. Sobre la efectividad de la justicia en las relaciones internacionales. In: El derecho internacional en un mundo en transformación: en homenaje al professor Eduardo Jimenez de Arechaga. Montevidéu: Fund. de Cultura Univ., 1994

RANGEL, Vicente Marotta. Solução pacifica de controvérsias. In: Comitê Jurídico Interamericano (Org.). XI Curso de derecho internacional. Cooperación de la Secretaria general de la OEA, Rio de Janeiro, agosto de 1984. Washington: O.E.A.- Secretaria General, 1985. p. 29-48.

REALE, Miguel. Avellar Brotero, ou a ideologia sob as Arcadas. In: . Horizontes do direito e da história: estudos de filosofia do direito e da cultura. São Paulo: Saraiva, 1956. p. 195-224.

REALE, Miguel. Filosofia em São Paulo. 2. ed. rev. e reestruturada. São Paulo: Grijalbo / EDUSP, 1976.

RODAS, João Grandino (Coord.). Contratos internacionais. 3. ed. São Paulo: Revista dos Tribunais, 2002

RODAS, João Grandino. A nacionalidade da pessoa física no Brasil, após 1988. In: BAPTISTA, Luis Olavo; HUCK, Hermes Marcelo; CASELLA, Paulo Borba (Orgs.). Direito e comércio internacional: estudos em homenagem ao prof. Irineu Strenger. São Paulo: LTr, 1994. p. 221-241 
RODAS, João Grandino. A nacionalidade da pessoa física. São Paulo: Revista dos Tribunais, 1990.

RODAS, João Grandino. Choice of law rules and the major principles of Brazilian private international law. In: DOLINGER, Jacob; ROSENN, Keith (Ed.). A panorama of Brazilian Law. Miami / Rio de Janeiro: Univ. of Miami North-South Center / Ed. Esplanada, 1992. p. 309-347

RODAS, João Grandino. Direito internacional privado brasileiro. São Paulo: Revista dos Tribunais, 1993

RODAS, João Grandino. Sociedade comercial e estado. Prefácio Fábio Konder Comparato. São Paulo: UNESP / Saraiva, 1995

RODAS, João Grandino; MONACO, Gustavo Ferraz de Campos. Conferência da Haia de direito internacional privado: a participação do Brasil. Brasília: FUNAG, 2007

RODAS, João Grandino; OLIVEIRA, Gesner. Direito e economia da concorrência. Rio de Janeiro: Renovar, 2004

RODRIGUES, Horácio Wanderlei. Novo currículo mínimo dos cursos jurídicos. São Paulo: Revista dos Tribunais, 1995.

SILVA, Geraldo Eulálio do Nascimento e. Le facteur temps et les traités. Recueil des Cours de l'Académie de Droit International, n. 154, p. 215-297, 1977.

SILVA, Luís Antonio da Gama e As qualificações em direito internacional privado. 1952. Monografia (Concurso à cátedra) - Faculdade de Direito, Universidade de São Paulo, São Paulo.

SODRÉ, Nelson Werneck. Síntese de história da cultura brasileira. 9. ed. Rio de Janeiro: Civilização Brasileira, 1981.

SPENGLER, Oswald. Der Untergang des Abendlandes: Umrisse eine Morphologie der Weltgeschichte. (C) 1923. Düsseldorf: Albatroz, Neudruck, 2007.

STRENGER, Irineu. Arbitragem comercial internacional. São Paulo: LTr, 1996

STRENGER, Irineu. Contratos internacionais do comércio. Prefácio L. G. Paes de Barros Leães. 1. ed. São Paulo: Revista dos Tribunais, 1986. (2. ed., rev. e ampl., 1992);

STRENGER, Irineu. Da autonomia da vontade em direito internacional privado. 1967. 230 p. Tese (Livre-docência) - Faculdade de Direito, Universidade de São Paulo, São Paulo.

STRENGER, Irineu. Direito do comércio internacional e lex mercatoria. Prefácio Fábio Konder Comparato. São Paulo: LTr, 1996.

STRENGER, Irineu. Direito internacional privado: parte geral, direito civil internacional, direito comercial internacional. 1. ed. São Paulo: Revista dos Tribunais, 1986

STRENGER, Irineu. Direito internacional privado: parte geral, direito civil internacional, direito comercial internacional. 4. ed., aumen. e atual. São Paulo: LTr, 2000 
STRENGER, Irineu. Direito moderno em foco. São Paulo: Revista dos Tribunais, 1986.

STRENGER, Irineu. La notion de lex mercatoria en droit du commerce international. Recueil de Cours de l'Académie de Droit International, Haye, n. 227, p. 207-356, 1991

STRENGER, Irineu. Mandado de injunção. Prefácio de J. Cretella Jr. Rio de Janeiro: Forense Universitária, 1988

STRENGER, Irineu. Prefácio. In: CASELLA, Paulo Borba. Comunidade européia e seu ordenamento jurídico. 2. ed. São Paulo: LTr, 1994, 2002

STRENGER, Irineu. Regime jurídico da reparação do dano em direito internacional privado. 1971. 275 p. Tese (Titular) - Faculdade de Direito, Universidade de São Paulo, São Paulo.

STRENGER, Irineu. Reparação do dano em direito internacional privado. Prefácio de Amílcar de Castro. São Paulo: Revista dos Tribunais, 1973

STRENGER, Irineu. Temas de formação filosófica. São Paulo: Revista dos Tribunais, 1986. 158 p.

STRENGER, Irineu. Teoria geral do direito internacional privado. São Paulo: José Bushatsky, 1973

VAMPRÉ, Spencer. Memórias para a história da Academia de São Paulo. 2. ed. Brasília: INL, 1977. p. 427-429

WEFFORT, Francisco; SOUZA, Márcio (Orgs.). Um olhar sobre a cultura brasileira. Prefácio de Fernando Henrique Cardoso. Rio de Janeiro: Associação dos Amigos da FUNARTE / Brasília: MinC, 1998.

WEIL, Prosper. Droit international public et droit administratif. In: Mélanges offerts à Mr. le Doyen Louis Trotabas. Paris: L.G.D.J., 1970.

WEIL, Prosper. Le droit international en quête de son identité. Recueil des Cours de l'Académie de Droit International, Haye, n. 237, p. 4-370, 1992. 